Research paper

\title{
Synthesis of cobalt(II)- $\alpha$-diimines complexes and their activity as mediators in organometallic mediated radical polymerization of vinyl acetate
}

\author{
Beatriz A. Riga ${ }^{\text {a }}$, Marina D. Neves ${ }^{a}$, Antonio E.H. Machado ${ }^{b}$, Diesley M.S. Araújo ${ }^{\text {b }}$, Jhonathan R. Souza ${ }^{\text {, }}$, \\ Otaciro R. Nascimento ${ }^{c}$, Vinícius T. Santana ${ }^{c}$, Carla C.S. Cavalheiro ${ }^{d}$, Valdemiro P. Carvalho-Jr ${ }^{a}$, \\ Beatriz E. Goi ${ }^{\text {a,* }}$ \\ ${ }^{a}$ Faculdade de Ciências e Tecnologia, UNESP Universidade Estadual Paulista, CEP 19060-900 Presidente Prudente, SP, Brazil \\ ${ }^{\mathrm{b}}$ Instituto de Química, UFU Universidade Federal de Uberlândia, CEP 38400-902 Uberlândia, MG, Brazil \\ ${ }^{\mathrm{c}}$ Instituto de Física de São Carlos, USP Universidade de São Paulo, CEP 13563-120 São Carlos, SP, Brazil \\ dinstituto de Química de São Carlos, USP Universidade de São Paulo, CEP 13566-590 São Carlos, SP, Brazil
}

\section{A R T I C L E I N F O}

\section{Article history:}

Received 17 July 2017

Received in revised form 11 October 2017

Accepted 22 November 2017

Available online 23 November 2017

\section{Keywords:}

$\alpha$-Diimine-cobalt complexes

CMRP

Vinyl acetate

Radical polymerization

\begin{abstract}
A B S T R A C T
This study describes the synthesis and characterization of three $\alpha$-diimine-cobalt complexes of the type $\left[\mathrm{CoCl}_{2}(\mathrm{R}-\mathrm{DAB})\right](\mathrm{R}-\mathrm{DAB}=\mathrm{R}-\mathrm{N}=\mathrm{CH}-\mathrm{CH}=\mathrm{N}-\mathrm{R} ; \mathrm{R}=\mathrm{Mes}$, Dipp and Dipp $*$ and their application as mediators for the cobalt-mediated radical polymerization (CMRP) of vinyl acetate (VAc) using 2,2'-Azobis(2methylpropionitrile) (AIBN) as initiator. The complexes were characterised by elemental analyses, FTIR, UV-Vis, electron paramagnetic resonance spectroscopy, cyclic voltammetry, and computational methods. The systematic variation of the reaction conditions, such as [initiator]/[Co] and [monomer]/[Co] molar ratios at $65{ }^{\circ} \mathrm{C}$, affected the polymerization rates and the molecular weights, reaching a certain level of control. The VAc polymerization was initiated by AIBN in the presence of DMSO using the $\alpha$-diiminecobalt complexes as mediators with $[\mathrm{DMSO}] /[\mathrm{Co}]=1$ at $65^{\circ} \mathrm{C}$. The control over the polymer produced was not improved after the addition of DMSO. Kinetics studies and computational investigations support a tailorable cobalt complex reactivity mainly altered by steric factors of the $\alpha$-diimine ligands.
\end{abstract}

(c) 2017 Elsevier B.V. All rights reserved.

\section{Introduction}

Since vinyl acetate (VAc) radical polymerization mediated by cobalt (CMRP) was first reported by Jérôme et al. [1], it became more than an answer to those who believed CMRP was efficient only for acrylic monomers; it became the most promising technique to achieve a highly efficient living radical polymerization (LRP) of this monomer [2]. This methodology belongs to a specific class of controlled polymerization named organometallic-mediated radical polymerization (OMRP) [3]. Effective control over VAc radical polymerization is desirable due to the fact that poly (vinyl acetate) (PVAc) can be exclusively produced by the radical mechanism [4] and, as additional motivation, there is a wide range of applications for PVAc, from ordinary applications as additives to paints or adhesive emulsions, to a large variety of conceivable new materials such as amphiphilic structures and nanofibrous material applied to hard tissue engineering $[2,4-8]$.

\footnotetext{
* Corresponding author.

E-mail address: beatriz_goi@fct.unesp.br (B.E. Goi).
}

These reasons are sufficient to motivate the exhaustive efforts of many researchers to find an ideal controlling system. It has long been reported by Jérôme and co-workers that $\left[\mathrm{Co}(\mathrm{acac})_{2}\right]$ can successfully mediate VAc polymerization, offering great results in terms of narrow molecular weight distribution, high monomer conversion, and linear dependence between molecular weight and conversion [9-11]. Even before that study, Wayland and coworkers had already reported cobalt porphyrinates that displayed only moderate control over the CMRP of VAc $[12,13]$. Recently, Peng et al. have announced the use of $\left[\mathrm{Co}\left(\right.\right.$ Salen $\left.\left.^{*}\right)\right]$ as a suitable controlling agent to promote the radical polymerization of VAc with large monomer conversion and high living character [14]. However, cobalt(II)- $\alpha$-diimine complexes for controlled radical polymerization of vinyl acetate have not been reported yet. A general mechanism illustrating the role played by cobalt complexes in CMRP reaction is presented in Scheme 1.

Thereby, to contribute to the advancement of research in CMRP of VAc, we herein report, for the first time, vinyl acetate radical polymerization mediated by cobalt(II)- $\alpha$-diimines. $\alpha$-Diimine ligands are molecules that have been extensively studied by Koten 


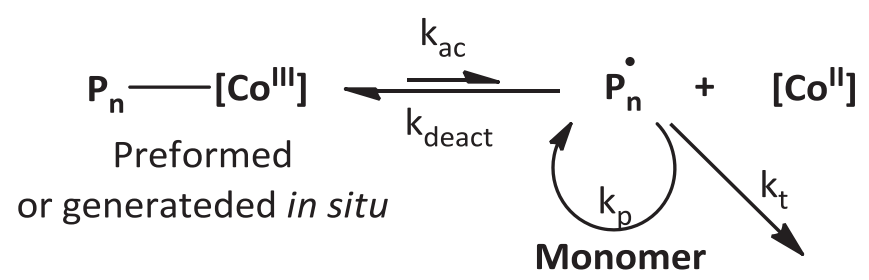

Scheme 1. General mechanism of cobalt-mediated radical polymerization.

and Vrieze [15]. This type of ligand presents a 1,4-diaza-1,3-butadiene skeleton $(\mathrm{N}=\mathrm{C}-\mathrm{C}=\mathrm{N})$ that has aroused much interest owing to its versatile coordination behaviour. When these ligands pertain to the class of 1,4-disubstituted 1,4-diaza-1,3-butadienes $(\mathrm{RN}=\mathrm{CH}-\mathrm{CH}=\mathrm{NR})$, they are frequently represented by the label $\mathrm{R}-\mathrm{DAB}$, where $\mathrm{R}$ is the functional group attached to the azomethine groups.

These ligands are bidentate, very rigid, and can easily have their backbone changed to modify the electronic and steric effects at the metal centre [16-20]. Moreover, diazabutadiene (or $\alpha$-diimine) ligands are able to stabilize metal centres in formally low oxidation states (such as cobalt II or III); this is a direct consequence of the presence of a low energy ligand-based $\pi^{*}$ orbital able to accept electron density from the metal, establishing a $\pi$ back-bonding $[21,22]$. $\mathrm{Fe}(\mathrm{II})$ and $\mathrm{Ni}(\mathrm{II})$ complexes bearing $\alpha$-diimine ligands have already been reported as catalysts for atom transfer radical polymerization of styrene and acrylic monomers [23,24], OMRP of VAc [25], and even $\alpha$-diimine-Co(II) complexes were applied as catalysts on polymerizations of other monomers such as ethylene [19] and 1,3-butadiene [20].

This study describes the synthesis and characterization of $\alpha$-diimine $\mathrm{Co}$ (II) complexes and their application as controlling agents for CMRP of VAc initiated by AIBN (2,2'-Azobis(2-methylpropionitrile)). The influences of the ligand structure, focusing the steric hindrance at the cobalt centre, were assessed by modification of the substituent on the 1 and 4 ligand positions. Different conditions of reaction time, concentrations of VAc and AIBN as initiator, as well as the use of DMSO as additive were investigated.

\section{Results and discussion}

\subsection{Synthesis and characterization}

$\alpha$-Diimines are excellent ligands for four-coordinate cobalt complexes due to their ease of preparation and their versatility to modification. They are readily prepared in high yield from the condensation of 2 equiv of the appropriate amine with 1 equiv of glyoxal [26-31]. The [Co(R-DAB)] complexes used in this study are shown in Scheme 2 (Mes =2,4,6-trimethylphenyl; Dipp = 2,6diisopropylphenyl; $\quad$ Dipp $^{*}=2,6$-(diphenylmethyl)-4-methylphenyl). The complexes 2a-c were prepared in good yields from the metallation of the corresponding R-DAB ligands with $\mathrm{CoCl}_{2}$ under mild conditions by stirring and heating at $40{ }^{\circ} \mathrm{C}$ (Scheme 3). The

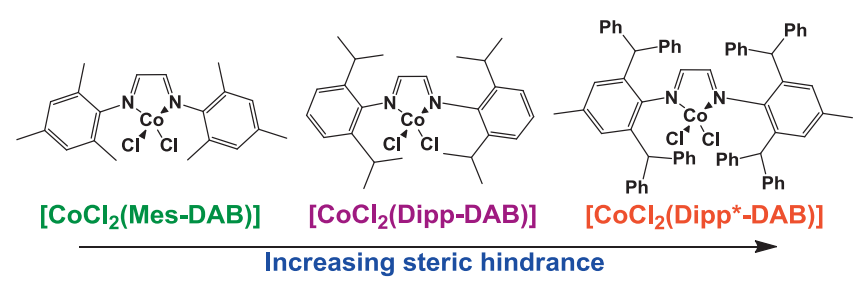

Scheme 2. Structures of cobalt(II)- $\alpha$-diimines complexes used to mediate vinyl acetate radical polymerization in this work.
FTIR and ${ }^{1} \mathrm{H}$ and ${ }^{13} \mathrm{C}$ NMR spectroscopic characteristics of the ligands 1a-c have been described in previous reports [32-34]. The complexes $\mathbf{2 a - c}$ were characterized by elemental analyses, cyclic voltammetry, FTIR, UV-Vis, EPR spectroscopy, and computational methods.

The experimental section shows the results of the elemental analyses $(\mathrm{C}, \mathrm{H}$, and $\mathrm{N})$; the results agree with those calculated for the suggested formula. Single crystals of the compounds could not be isolated from any organic solution, thus no definite structures can be described. However, the analytical and spectroscopic data enable us to predict possible structures. The FTIR spectra of ligands 1a-c indicate absence of peaks attributable to carbonyl and amino groups, and the appearance of new peaks between $1624-1612 \mathrm{~cm}^{-1}$ is assigned to $v(\mathrm{C}=\mathrm{N})$ stretching vibration (Table 1). These peaks confirm the formation of the corresponding azomethine group. The latter bands are also observed in the FTIR spectra of complexes $2 \mathbf{a}-\mathbf{c}$ in the range $1630-1590 \mathrm{~cm}^{-1}$. These bands in the complexes are shifted to lower wavenumbers when compared with the ligands, suggesting the participation of azomethine nitrogen atoms in the coordination. Additional bands between 260 and $290 \mathrm{~cm}^{-1}$ are also observed in the spectra of all complexes assigned to $v(\mathrm{Co}-\mathrm{N})$ stretching vibration, which confirms the coordination of azomethine nitrogen atoms to the Co centre. The bands in the region of $300-345 \mathrm{~cm}^{-1}$ are assigned to $v(\mathrm{Co}-\mathrm{Cl})$ stretching vibrations. This assignment is quite reasonable and in agreement with previous assignments for related tetrahedral complexes [16-19].

The electronic spectra of the free ligands and cobalt(II) complexes were recorded in $\mathrm{CH}_{2} \mathrm{Cl}_{2}$. The absorption spectra of $\mathbf{1 a}-\mathbf{c}$ exhibit absorption peaks at the regions of $259 \mathrm{~nm}$ and 297-365 $\mathrm{nm}$ (Table 1 ). The bands at higher energy arise from $n-\pi^{*}$ transitions and are associated with the azomethine chromophore, whereas the bands at lower energy are attributable to $\pi-\pi^{*}$ transitions within the phenyl rings [35]. All compounds display an intense band at approximately $230 \mathrm{~nm}$; this excitation is attributed to the $\pi-\pi^{*}$ transitions arising from the azomethine group [16,17]. The absorption spectra of $2 a-c$ exhibit excitations between $260-$ $326 \mathrm{~nm}$, which are assignable to ligand-to-cobalt(II) charge transfer. Two transitions that give rise to broad bands between 502 and $631 \mathrm{~nm}$ are also observed: The absorption at higher energy occurs due to cobalt(II)-to-ligand charge transfer and the absorption at lower energy is attributed to metal-ligand bonding-to-antibonding transition, the latter transition is provided by the mixing between the metal $\mathrm{d} \pi$ and R-DAB ligand $\mathrm{p} \pi^{*}$ orbitals ( $\pi$ back-bonding) [36].

\subsection{EPR spectra}

EPR spectra of complexes $\mathbf{2 a}-\mathbf{c}$ were recorded at $\mathrm{T}=5 \mathrm{~K}$ from powder samples (not shown) and from the frozen $\mathrm{CH}_{2} \mathrm{Cl}_{2}$ solutions of the samples that are shown in Fig. 1. All samples presented a broad signal characteristic of $\mathrm{Co}^{\text {II }}$ ions with a high spin $\mathrm{S}=3 / 2$ configuration in distorted tetrahedral symmetry. Powder and frozen solution spectra differed only in the linewidth values because mag-

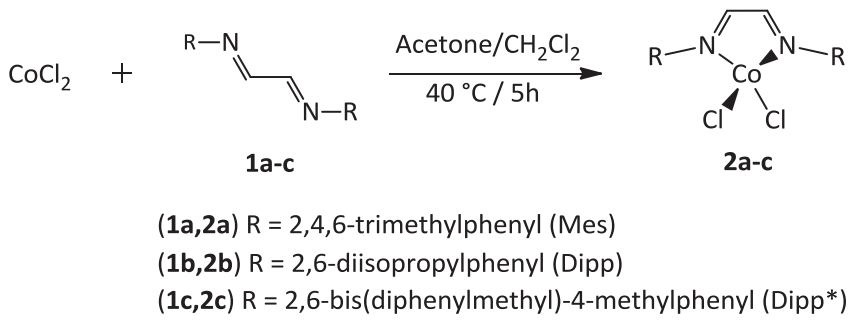


Table 1

Infrared and electronic absorption data for R-DAB ligands and $\left[\mathrm{CoCl}_{2}(\mathrm{R}-\mathrm{DAB})\right]$ complexes.

\begin{tabular}{|c|c|c|c|c|}
\hline \multirow[t]{2}{*}{ Ligand/Complex } & \multicolumn{2}{|l|}{$\operatorname{FTIR}\left(\mathrm{cm}^{-1}\right)$} & \multicolumn{2}{|c|}{ UV-Vis (nm) } \\
\hline & Ligand $v(\mathrm{C}=\mathrm{N})$ & Complex & Ligand & Complex \\
\hline $1 \mathbf{a} / 2 \mathbf{a}$ & 1612 & $\begin{array}{l}1593 v(\mathrm{C}=\mathrm{N}) \\
343 v(\mathrm{Co}-\mathrm{Cl}) \\
312 v(\mathrm{Co}-\mathrm{Cl}) \\
280 v(\mathrm{Co}-\mathrm{N})\end{array}$ & $\begin{array}{l}236\left(\pi-\pi^{*}\right) \\
259\left(n-\pi^{*}\right) \\
365\left(\pi-\pi^{*}\right)\end{array}$ & $\begin{array}{l}234\left(\pi-\pi^{*}\right) \\
326(\mathrm{LMCT}) \\
502(\mathrm{MLCT}) \\
592\left(\mathrm{~d} \pi-\pi^{*}\right)\end{array}$ \\
\hline $1 \mathbf{b} / 2 \mathbf{b}$ & 1624 & $\begin{array}{l}1600 v(\mathrm{C}=\mathrm{N}) \\
310 v(\mathrm{Co}-\mathrm{Cl}) \\
300 v(\mathrm{Co}-\mathrm{Cl}) \\
279 v(\mathrm{Co}-\mathrm{N})\end{array}$ & $\begin{array}{l}231\left(\pi-\pi^{*}\right) \\
256\left(n-\pi^{*}\right) \\
357\left(\pi-\pi^{*}\right)\end{array}$ & $\begin{array}{l}231\left(\pi-\pi^{*}\right) \\
323(\mathrm{LMCT}) \\
406(\mathrm{MLCT}) \\
631\left(\mathrm{~d} \pi-\pi^{*}\right)\end{array}$ \\
\hline $1 c / 2 c$ & 1624 & $\begin{array}{l}1630 v(\mathrm{C}=\mathrm{N}) \\
312 v(\mathrm{Co}-\mathrm{Cl}) \\
297 v(\mathrm{Co}-\mathrm{Cl}) \\
279 v(\mathrm{Co}-\mathrm{N})\end{array}$ & $\begin{array}{l}231\left(\pi-\pi^{*}\right) \\
259\left(n-\pi^{*}\right) \\
297\left(\pi-\pi^{*}\right)\end{array}$ & $\begin{array}{l}231\left(\pi-\pi^{*}\right) \\
260(\mathrm{LMCT}) \\
521(\mathrm{MLCT}) \\
626\left(\mathrm{~d} \pi-\pi^{*}\right)\end{array}$ \\
\hline
\end{tabular}

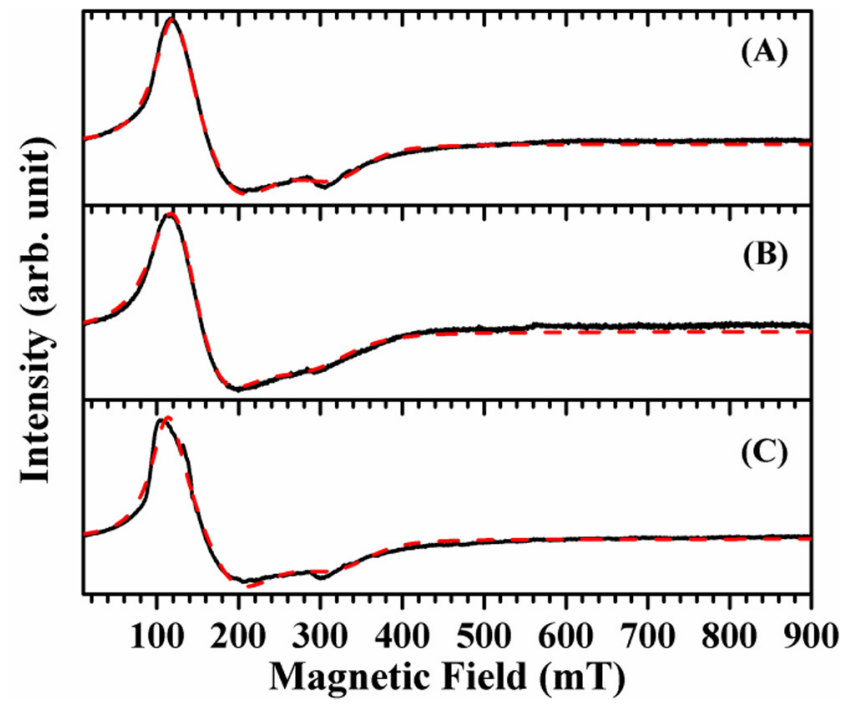

Fig. 1. Frozen $\mathrm{CH}_{2} \mathrm{Cl}_{2}$ solution EPR spectra (-) and simulations (- - -) of $\mathbf{2 a}(\mathrm{A}), \mathbf{2 b}$ (B) e $2 c(C)$.

netic dipolar interactions among neighbours broadened the powder EPR spectra. EasySpin [37], a package of programs working under Matlab [38], was used to simulate the experimental spectra. The spin Hamiltonian describing these systems is

$\mathrm{H}_{0}=\mu_{B} B \cdot(g \cdot S)+\mathrm{S} \cdot \mathrm{D} \cdot \mathrm{S}$

where $\mu_{\mathrm{B}}$ is the Bohr magneton, $\mathbf{B}$ is the applied magnetic field, $\mathbf{g}$ is the giromagnetic tensor and $\mathbf{D}$ is the zero field splitting expressed by the two components $D$ and $E$ (axial and rhombic terms, respectively). The ratio $E / D$ expresses the distortion of the symmetry and is usually limited to the interval $0 \leq E / D \leq 1 / 3$, where 0 indicates perfect axial symmetry and $1 / 3$ indicates the maximum distortion in the z-direction $\left(\left|D_{z z}\right|\right.$ or $\left.\left|D_{33}\right|\right)$ and minimum in the $\mathrm{x}$ direction $\left(\left|D_{11}\right|\right)$. The spectra are characteristic of transitions in the lower $\mid 3 / 2, \pm 1 / 2>$ doublet populated at low temperatures. Simulations of the frozen solution spectra were first performed considering effective $g^{\prime}$ values for an $S^{\prime}=1 / 2$ effective spin in order to estimate the E/D values [18] and are shown in Fig. 1. Simulations of the spectra at $\mathrm{T}=5 \mathrm{~K}$ using Eq. (1) for $\mathrm{C}^{\mathrm{II}}$ ions with a high spin $\mathrm{S}=3 / 2$ configuration and distorted tetrahedral symmetry were used to estimate the minimum value of $\mathrm{D}$ parameters.

The EPR parameters obtained from these simulations are described in Table 2 . The best simulations gave $g$ values and $D$ values in agreement with the references [18,39-41] despite the uncertainty imposed by the broad linewidths. $E / D$ ratios are similar for the three complexes studied and indicates a rhombic distortion in the range $22 \%-35 \%$ in comparison with the maximum distortion $(E / D=1 / 3)$.

\subsection{Theoretical calculations}

The optimized structures of the pseudo-tetrahedral $\mathrm{Co}$ (II)- $\alpha$-diimine complexes are presented in Fig. 2. Relevant bond distances and angles of the studied complexes are presented in Table 3. The atoms follow the numbering shown in Fig. 4. As expected, all these complexes form distorted tetrahedrals. The $\mathrm{Co}-\mathrm{Cl}$ distances are longer than $\mathrm{Co}-\mathrm{N}$ distances, and the solvation of these complexes tends to increase some geometrical parameters, enlarging the distortion of the tetrahedral structure. The data in Table 2 suggests that the dihedral angle $(\mathrm{N}-\mathrm{C}-\mathrm{C}-\mathrm{N})$ of the five-membered ring involving the $\mathrm{Co}(\mathrm{II})$ and the nitrogen atoms is strongly influenced by the amount and size of the substituents present in the phenyl groups. The parameters g1, g2, and g3, obtained theoreti-

Table 2

EPR parameters obtained from EPR spectra and using DFT single-point calculations.

\begin{tabular}{|c|c|c|c|c|c|c|c|}
\hline Sample & g1 & g2 & g3 & Linewidth $^{\mathrm{a}}$ & H Strain $^{\mathrm{b}}$ & $\mathrm{D}^{\mathrm{c}}$ & E/D \\
\hline $2 a$ & $5.3543^{\mathrm{e}}$ & $4.0012^{\mathrm{e}}$ & $2.0707^{\mathrm{e}}$ & 52 & $(0,66,59)$ & $>6$ & 0.096 \\
\hline REVPBE $^{\mathrm{d}}$ & 2.0571 & 2.1119 & 2.0804 & & & -4.01 & 0.026 \\
\hline $\mathbf{2 b}$ & $5.4162^{\mathrm{e}}$ & $4.3435^{\mathrm{e}}$ & $2.2440^{\mathrm{e}}$ & 71 & $(0,42,72)$ & $>6$ & 0.073 \\
\hline REVPBE & 2.0569 & 2.1129 & 2.0807 & & & -4.07 & 0.029 \\
\hline $2 c$ & $5.6826^{\mathrm{e}}$ & $3.9754^{\mathrm{e}}$ & $2.0509^{e}$ & 46 & $(0,68,74)$ & $>6$ & 0.118 \\
\hline REVPBE & 2.0819 & 2.3787 & 2.0784 & & & -20.74 & 0.038 \\
\hline
\end{tabular}

a Linewidth in $\mathrm{mT}$.

b Anisotropic broadening in $\mathrm{mT}$ for the directions of $\mathrm{g} 1, \mathrm{~g} 2$ and $\mathrm{g} 3$.

c $\mathrm{D}$ in $\mathrm{cm}^{-1}$.

d The GGA functional REVPBE was used to calculate g1, g2, g3, and D and E/D were estimated using the diagonal terms of the ZFS tensor [42], calculated using the functional BP86 [43].

e Effective $g$ values. 


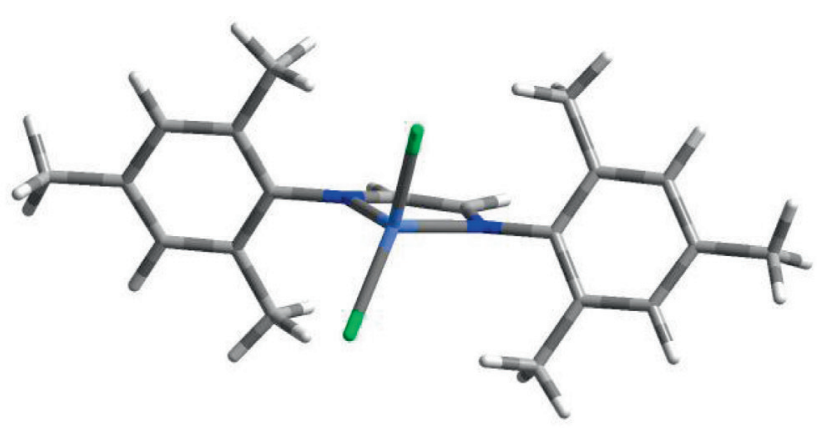

Complex 2a

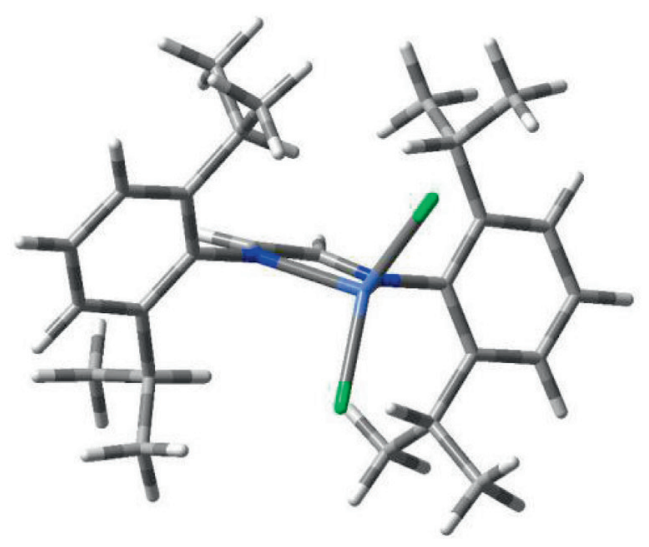

Complex 2b

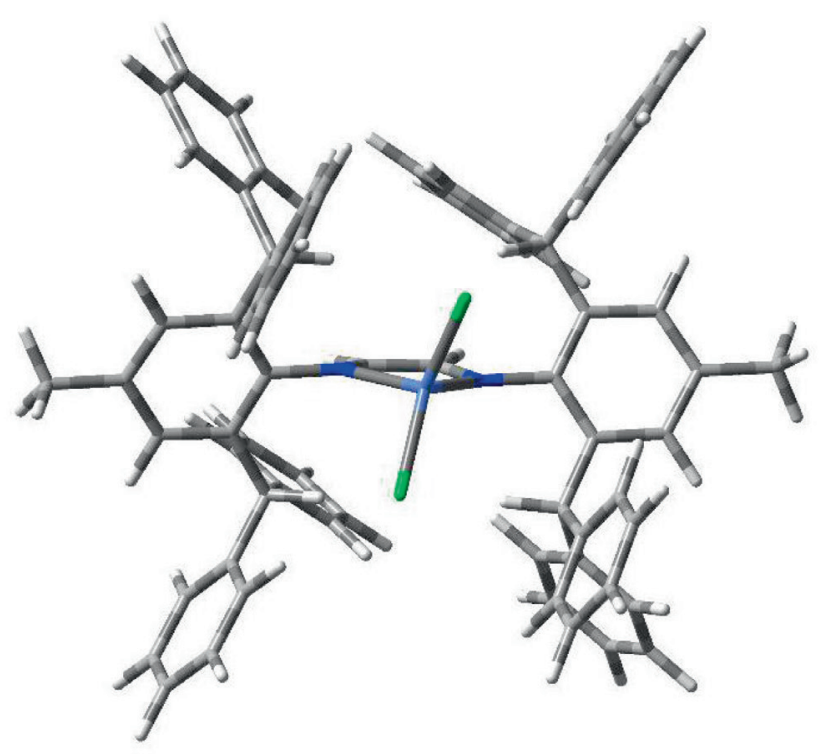

\section{Complex 2c}

Fig. 2. Views of the optimized structures of complexes $\mathbf{2 a}, \mathbf{2} \mathbf{b}$, and $\mathbf{2 c}$.

cally, are consistent with what is expected of species submitted to a field of rhombic symmetry [18-40] and compatible with pseudotetrahedral $\mathrm{Co}(\mathrm{II})$ complexes that display the general formula $\mathrm{CoL}_{2}-$ $X_{2}$ [39]. Regarding the parameter E/D, although smaller than the values estimated from experimental parameters, the theoretical values also suggest a high rhombic distortion, similarly to the experimental values. It should be emphasized that, in an environment with maximum rhombicity, the ratio E/D is limited to 0.33 [42]. Analysis of the geometric parameters estimated for these compounds, either isolated or solvated (Table 3), shows that they are distorted tetrahedrals in the vicinity of $\mathrm{Co}(\mathrm{II})$. It can also be noticed that the two substituent groups anchored to the aromatic structures attached to these rings play no determining role on the distortion and general geometry of these complexes. However, although in a small extension, tension is reduced for the solvated structures especially between cobalt and chlorides.

It should be emphasized that the angles $\mathrm{Cl}-\mathrm{Co}-\mathrm{Cl}$ shown in Table 3 for the non-solvated complexes, of approximately $137^{\circ}$ for the complexes $\mathbf{2 a}$ and $\mathbf{2} \mathbf{b}$, correspond to a deviation of nearly $23 \%$ with respect to the expected for a tetrahedral compound based on $\mathrm{Co}(\mathrm{II})$, Fig. 3, consistent with the rhombic distortion in the range of $22-35 \%$ in comparison with the maximum distortion [42]. For complex 2c, the lowest value found for the $\mathrm{Cl}-\mathrm{Co}-\mathrm{Cl}$ angle $\left(129^{\circ}\right)$ is due to the angular tension caused by the groups diphenylmethyl, Fig. 2, leading to a minor deviation (16\%). In contrast, for the angle $\mathrm{N}-\mathrm{Co}_{\mathrm{O}}-\mathrm{N}$, the estimated deviations with respect to the expected in a non-distorted tetrahedron $\left(103^{\circ}\right)$ are larger: $32 \%$ for $\mathbf{2 a}$ and $\mathbf{2 b}$, and $29 \%$ for $\mathbf{2 c}$, respectively.

\subsection{Cyclic voltammetry}

The electrochemical activity of the complexes $\mathbf{2 a - c}$ was studied by cyclic voltammetry in scan rate of $100 \mathrm{mV} \mathrm{s}^{-1}$ in $\mathrm{CH}_{2} \mathrm{Cl}_{2}$ solution containing $0.1 \mathrm{Mn}$-Bu $\mathrm{NPF}_{6}$ as supporting electrolyte. Under these conditions the redox potential $\left(E_{1 / 2}\right)$ for the $\mathrm{Fc} / \mathrm{Fc}^{+}$couple occurred at $470 \mathrm{mV}$, with $\Delta E_{\mathrm{p}}=208 \mathrm{mV}$; results for $\mathbf{2 a}$-c are collected in Table 4. $E_{1 / 2}$ values lie in the range from -269 to $-630 \mathrm{mV}$, indicating that the $\mathrm{Co}(\mathrm{II})$ centres are readily oxidized and potentially suited to facile organo-cobalt(III) formation (Table 4) [44]. Their peakto-peak separations $\left(\Delta E_{\mathrm{p}}\right)$ are lower to the ferrocene-ferrocenium couple, indicating that these $\mathrm{Co}^{\mathrm{II}} / \mathrm{Co}^{\mathrm{III}}$ couples are facile and reversible. The peak-to-peak separation, $\Delta E_{\mathrm{p}}$, is somewhat larger than the canonical value for ideal Nernstian behavior $(59 \mathrm{mV})$, indicating some reorganization of the coordination sphere of the cobalt centre. This may reflect preferred coordination geometries for each redox state, $\mathrm{Co}^{\mathrm{II}}, \mathrm{d}^{7}$ and $\mathrm{Co}^{\mathrm{III}}, \mathrm{d}^{6}$. One-electron redox processes in the region between -700 and $-250 \mathrm{mV}$ and an irreversible oxidation process above $750 \mathrm{mV}$ were observed for all complexes. The first redox process can be assigned to the $\mathrm{CO}^{\mathrm{II}} / \mathrm{CO}^{\mathrm{III}}$ metal centre and the more positive oxidation potential is assigned to the arylimine moieties. Overall, there is a clear shift in the $\mathrm{Co}^{\mathrm{II}} / \mathrm{Co}^{\mathrm{III}}$ redox potentials towards more positive values as the electron-withdrawing ability of the aryl substituents is increased (Dipp* $>$ Mes > Dipp).

\subsection{CMRP of VAC}

The complexes $\mathbf{2 a - c}$ were used as mediators for the polymerization of VAc in bulk at $65^{\circ} \mathrm{C}$. To begin this study, a variation of [initiator]/[Co] ratio was performed to find the best reaction condition to control the production of radicals. The effect of the [AIBN]/ [Co] molar ratio on the VAc conversion is illustrated in Fig. 5. The conversion values showed favourable dependence on the [AIBN]/ [Co] molar ratio in the range from 0.5 to 11.5 at $65^{\circ} \mathrm{C}$ for $12 \mathrm{~h}$. The conversions increase exponentially throughout the evaluated concentration range in all cases. $\mathrm{Co}(\mathrm{II})-\alpha$-diimines $(\mathbf{2 a}-\mathbf{c})$ mediated VAc polymerization seem to be mainly controlled by degenerative transfer (DT) process as well since this polymerization requires an extra equivalent of radicals, once only reach low monomer conversion with $[\mathrm{AIBN}] /[\mathrm{Co}]=0.5 . \mathrm{M}_{\mathrm{n}}$ values for $\mathbf{2 a}-\mathbf{b}$ show a curve with profile similar to those of conversion, which presents an increase in 
Table 3

Relevant bond distances and angles related to the studied $\mathrm{Co}(\mathrm{II})$ complexes in the gas phase. The values in parenthesis are related to the complex in dichloromethane.

\begin{tabular}{|c|c|c|c|}
\hline \multirow[t]{2}{*}{ Geometric parameter } & \multicolumn{3}{|l|}{ Complexes } \\
\hline & $\mathbf{2 a}$ & $\mathbf{2 b}$ & 2c \\
\hline $\mathrm{d}\left(\mathrm{Co}-\mathrm{Cl}_{(3)}\right), \AA$ & 2.2249 (2.2620) & $2.2235(2.2600)$ & $2.2170(2.2630)$ \\
\hline $\mathrm{d}\left(\mathrm{Co}-\mathrm{Cl}_{(2)}\right), \AA$ & $2.2250(2.2622)$ & $2.2235(2.2600)$ & $2.2170(2.2588)$ \\
\hline $\mathrm{d}\left(\mathrm{Co}-\mathrm{N}_{(5)}\right), \AA$ & $2.1020(2.1140)$ & $2.1034(2.1196)$ & $2.1190(2.1167)$ \\
\hline $\mathrm{d}\left(\mathrm{Co}-\mathrm{N}_{(4)}\right), \AA$ & $2.1015(2.1143)$ & 2.1036 (2.1197) & $2.1191(2.1080)$ \\
\hline $\mathrm{d}\left(\mathrm{C}_{(18)}-\mathrm{N}_{(5)}\right), \AA$ & $1.4243(1.4192)$ & $1.4272(1.4212)$ & $1.4264(1.4175)$ \\
\hline $\mathrm{d}\left(\mathrm{C}_{(10)}-\mathrm{N}_{(4)}\right), \AA$ & $1.4244(1.4189)$ & $1.4271(1.4212)$ & $1.4264(1.4204)$ \\
\hline$\Theta\left(\mathrm{Cl}_{(3)}-\mathrm{Co}-\mathrm{Cl}_{(2)}\right){ }^{\circ}$ & $137.252(119.082)$ & $137.485(118.466)$ & $128.644(117.538)$ \\
\hline$\Theta\left(\mathrm{N}_{(5)}-\mathrm{Co}-\mathrm{N}_{(4)}\right),{ }^{\circ}$ & $78.284(79.791)$ & $78.290(79.681)$ & $80.222(80.353)$ \\
\hline$\Theta\left(\mathrm{Cl}_{(3)}-\mathrm{Co}-\mathrm{N}_{(5)}\right),{ }^{\circ}$ & $111.853(120.084)$ & $101.000(106.142)$ & $102.057(105.497)$ \\
\hline$\Theta\left(\mathrm{Cl}_{(2)}-\mathrm{Co}-\mathrm{N}_{(4)}\right)$ & $111.646(120.240)$ & $100.978(106.141)$ & $102.049(107.122)$ \\
\hline $\mathrm{D}\left(\mathrm{N}_{(5)} \mathrm{C}_{(7)}-\mathrm{C}_{(6)} \mathrm{N}_{(4)}\right),{ }^{\circ}$ & $-9.222(-12.251)$ & $8.696(11.185)$ & $9.817(8.439)$ \\
\hline
\end{tabular}

molecular weights of polyVAc up to $[\mathrm{AIBN}] /[\mathrm{Co}]=11.5$, whereas for 2c the $M_{n}$ values reach a maximum at 3.25 followed by a drop for higher ratios. For $[\mathrm{AIBN}] /[\mathrm{Co}]$ ratio $\geq 1.5$, the CMRP mechanism becomes mostly DT, which requires the rapid exchange of the propagating radicals by the controlling agents in order to minimize the termination reactions. For complex $\mathbf{2 c}$ the increase of the ratio

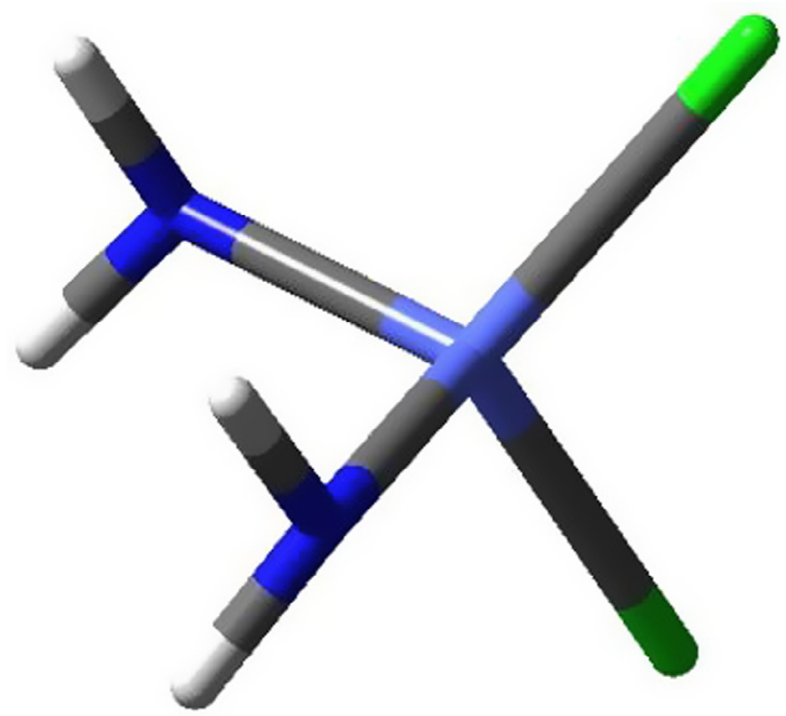

Fig. 3. Representation of the tetrahedral compound $\mathrm{Co}\left(\mathrm{NH}_{2}\right)_{2} \mathrm{Cl}_{2}$ : the angles $\mathrm{Cl}-\mathrm{Co}-\mathrm{Cl}$ and $\mathrm{N}-\mathrm{Co}-\mathrm{N}$ are, respectively, $110.96^{\circ}$ and $103.31^{\circ}$. This structure was optimized under conditions similar to those used in the structural optimization of the other complexes.

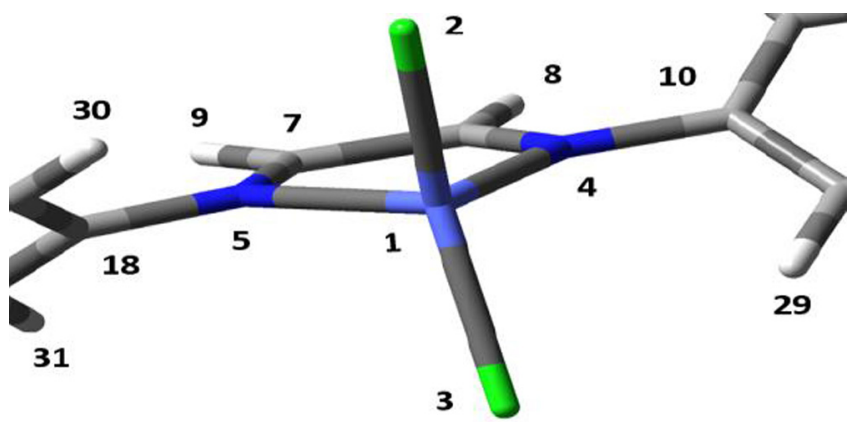

Fig. 4. Representation of the central part of the complexes showing the numbered atoms. Colours of the atoms: white for hydrogen, grey for carbon, blue for nitrogen, light blue for cobalt, and green for chlorine.
[AIBN]/[Co] from 3.25 decreases the Mn values, even though an increase in the conversion values is observed. This clearly indicates that the greater steric hindrance in the complex $\mathbf{2 c}$ prevents the deactivation of the propagating radicals and favours the chain termination reactions, which consequently results in lower molecular weights.

For $[$ AIBN $] /[C o]=3.25$, narrow $\left(\mathrm{M}_{\mathrm{w}} / \mathrm{M}_{\mathrm{n}}=1.40-1.42\right)$ molecular weight distributions of polyVAc were obtained with $\mathbf{2 a}$ and $\mathbf{2 b}$, whereas a broad distribution $\left(M_{w} / M_{n}=2.10\right)$ was obtained with 2c. An increase of AIBN concentration resulted in polymers even more disperse, with $Đ$ values higher than 1.5. Therefore, considering the good results obtained, this AIBN concentration ([AIBN]/ $[\mathrm{Co}]=3.25$ ) was selected for the upcoming studies.

The effect of the $[\mathrm{VAc}] /[\mathrm{Co}]$ molar ratio on the conversion of isolated polymer is presented in Table 5. Polymerization appeared to

Table 4

Cyclic voltammetry ${ }^{\mathrm{a}}$ results for complexes $\mathbf{2 a} \mathbf{a}-\mathbf{c}$ in the absence/presence of DMSO.

\begin{tabular}{llllll}
\hline & \multicolumn{2}{l}{ Absence of DMSO } & & & Presence of DMSO $^{\mathrm{b}}$ \\
\cline { 2 - 3 } \cline { 5 - 6 } & $E_{1 / 2}\left(E_{\mathrm{ox}}\right) / \mathrm{mV}$ & $\Delta E_{\mathrm{p}} / \mathrm{mV}$ & & $E_{1 / 2}\left(E_{\text {ox }}\right) / \mathrm{mV}$ & $\Delta E_{\mathrm{p}} / \mathrm{mV}$ \\
\hline 2a & $-323(-279)$ & 87 & & $-313(-279)$ & 68 \\
2b & $-630(-585)$ & 91 & & $-658(-615)$ & 86 \\
2c & $-269(-223)$ & 92 & & $-307(-268)$ & 77
\end{tabular}

a Conditions: $\mathrm{CH}_{2} \mathrm{Cl}_{2}, \mathrm{n}-\mathrm{Bu}_{4} \mathrm{NPF}_{6}$ (supporting electrolyte, $0.1 \mathrm{~mol} \mathrm{~L}^{-1}$ ), [Co] $=5$ mmol L $\mathrm{L}^{-1}$, scan rate $=100 \mathrm{mV} \mathrm{s}^{-1}$ ), platinum disk and wire (working and auxiliary electrode), $\mathrm{Ag} / \mathrm{AgCl}$ (reference electrode). $\mathrm{E}_{1 / 2}$ is the half-wave potential for the complex; $\Delta \mathrm{E}_{\mathrm{p}}$ is the cathodic-anodic peak separation

b $[\mathrm{DMSO}] /[\mathrm{Co}]=1$.

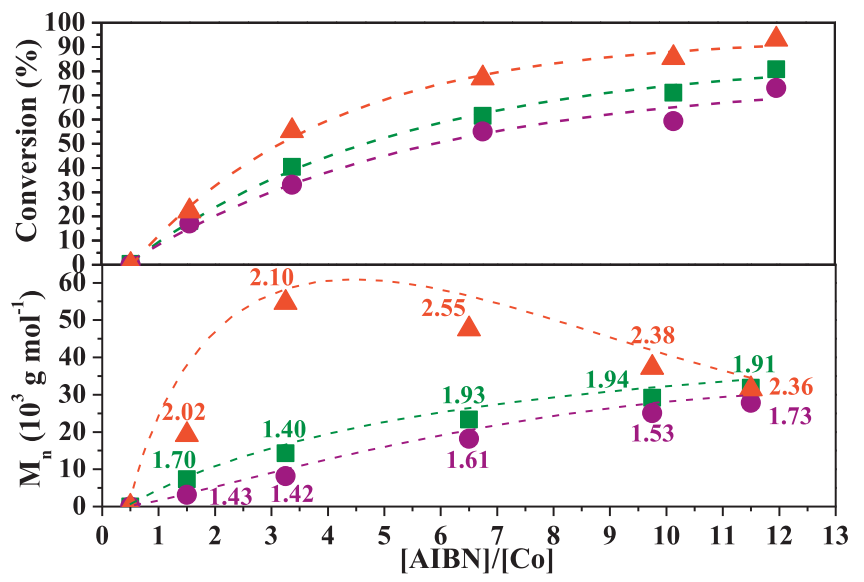

Fig. 5. Dependence of conversion and $M_{n}$ values on the $[A I B N] /[C o]$ ratio for CMRP of VAc with $\mathbf{2 a}(\boldsymbol{\square}), \mathbf{2 b}(\bullet)$ and $\mathbf{2 c}(\mathbf{\Delta})$; [VAc]/[Co] = 542 with $40 \mu \mathrm{mol}$ of complex in bulk at $65{ }^{\circ} \mathrm{C}$ for $12 \mathrm{~h}$. The numbers correspond to the $Đ$ values for each run. 
be sensitive to the monomer/mediator ratio, with a decrease in the conversion values of polyVAc with the increase of the [VAc]/[Co] ratio for all complexes. Furthermore, an increase in the [VAc]/ [Co] ratio resulted in broader $Ð$ and molecular weights higher than the predicted ones. This can be explained by the fact that higher [VAc]/[Co] ratio imply in a decrease in the concentration of AIBN, and thus the concentration of radicals. With declined radical concentration, the polymerization rate decreases as well as the VAc conversion. The experimental molecular weights closer to the theoretical values with narrowest $Đ$ values were obtained with [VAc]/ $[\mathrm{Co}]=542$, suggesting the most satisfactory VAc concentration for the upcoming studies.

CMRP of VAc mediated by $\mathbf{2 a - c}$ as a function of time under established optimal conditions ([VAc]/[AIBN]/[Co] $=542 / 3.25 / 1$ at $65{ }^{\circ} \mathrm{C}$ ) showed a similar length of induction period ( $\left.\sim 270 \mathrm{~min}\right)$ and first order kinetic plots with different slopes, as assessed by the linear dependence of $\ln \left([\mathrm{M}]_{0} /[\mathrm{M}]_{\mathrm{t}}\right)$ versus time (Fig. 6). The slope in the first-order kinetic plots allowed us to calculate the kinetic constants of reactions mediated by each one of the complexes $\left(k_{\text {obs }}=1.96 \times 10^{-5} \cdot \mathrm{s}^{-1}\right.$ for $2 \mathrm{a}, k_{\mathrm{obs}}=1.62 \times 10^{-5} \cdot \mathrm{s}^{-1}$ for $\mathbf{2 b}$, and $k_{\mathrm{obs}}=2.55 \times 10^{-5} \cdot \mathrm{s}^{-1}$ for $\mathbf{2 c}$ ). The induction period was rationalized as the time required to form organo- $\mathrm{Co}$ (III) complexes from the $\mathrm{Co}(\mathrm{II})$ species and radicals $[45,46]$. Nevertheless, the theoretical molecular weights predicted were higher than those obtained experimentally. The molecular weight distribution curves were monomodal throughout the polymerization (Fig. S14). A linear increase of molecular weight with conversion (Fig. 7), coupled with Đs $<1.43$, illustrate a certain control that $\mathbf{2 a - b}$ exert over polymerizations of VAc. In contrast, the molecular weight of polyVAc did not increase linearly as a function of VAc conversion and presented high $Ð$ values when mediated by $\mathbf{2 c}$. The molecular weights were high from the beginning, much higher than the calculated values, and did not depend linearly on conversion. Shaver and co-workers conducted a systematic variation of ligand substituents in cobalt complexes correlating with their redox potential for a better understanding of the role of the metal-carbon bond strengths towards improved control and tunability of polymerisations [47]. The studies pointed out that an increase in the electron density around the metal centre (lower redox potential) favours the increase of the conversion, but to a loss of controllability in the polymerization. When evaluating the mediating efficiency of complexes $\mathbf{2 a - c}$, better control levels were achieved with the complexes with lower redox potential. However, it is clear that steric effects also play an important role in determining the reactivity of complexes 2a-c. A smaller discrepancy between observed and calculated molecular weight, and narrower molecular weight distribution were obtained for less sterically hindered complexes. It can be proposed that higher steric hindrance restricts the equilibrium between the mediator and the propagating radical species.

CMRP of vinyl monomers in the presence of DMSO mediated by organocobalt has already been reported as a strategy to achieve

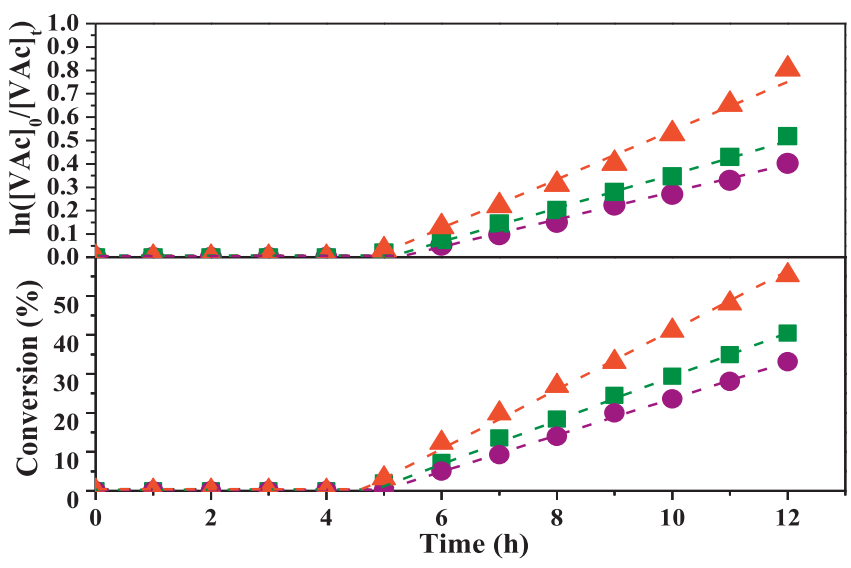

Fig. 6. Dependence of $\ln \left([\mathrm{VAc}]_{0} /[\mathrm{VAc}]_{\mathrm{t}}\right)$ conversion on the reaction time for CMRP of VAc with $\mathbf{2 a}(\boldsymbol{\square}), \mathbf{2 b}(\bullet)$ and $\mathbf{2 c}(\mathbf{\Delta})$; [Co]/[AIBN]/[VAc] = 1/3.25/542 with $40 \mu \mathrm{mol}$ of complex in bulk at $65^{\circ} \mathrm{C}$.

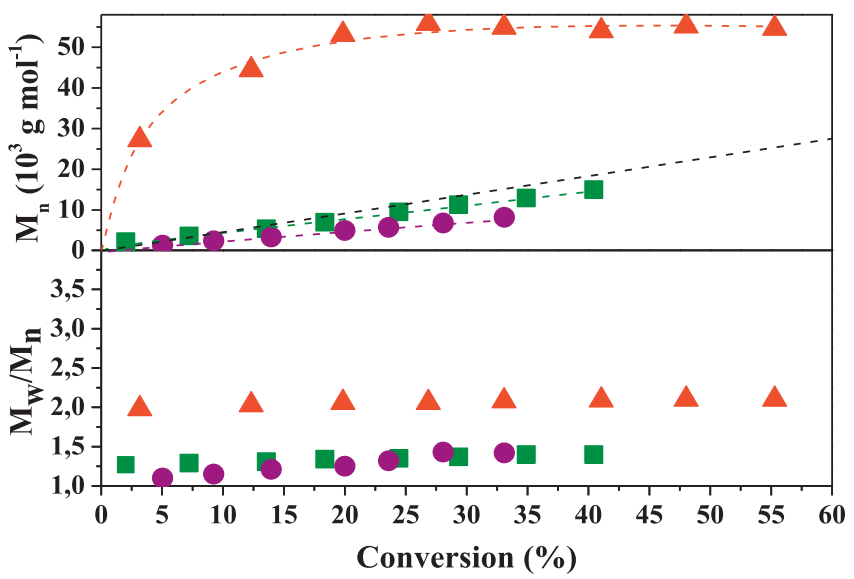

Fig. 7. Dependence of $M_{n}$ and $Đ$ on the conversion for CMRP of VAc with $2 \mathbf{a}(\boldsymbol{\square}), \mathbf{2 b}$ (•) and 2c $(\mathbf{\Delta})$; [Co]/[AIBN]/[VAc] $=1 / 3.25 / 542$ with $40 \mu \mathrm{mol}$ of complex in bulk at $65^{\circ} \mathrm{C} ; \mathrm{M}_{\mathrm{n} \text { (theor) }}$ (black dashed-line).

better levels of control in polymerization [48-52]. These studies suggest that the coordination of DMSO to the Co centre exerts a trans effect to facilitate the weakening of the $\mathrm{C}-\mathrm{Co}$ bond in the axial plan, favoring the exchange of radicals by the reversible termination mechanism. In light of this results, VAc polymerization was initiated by AIBN in the presence of DMSO using 2a-c as mediators with $[\mathrm{DMSO}] /[\mathrm{Co}]=1$ at $65^{\circ} \mathrm{C}$. Using this ratio, a DMSO molecule coordinates to the cobalt centre and the VAc polymerization, previously conducted by the DT pathway, is reverted to a reversible termination (RT) mechanism due to the blocked reaction site. All

Table 5

Bulk polymerization of VAc with different amounts of VAc at $65^{\circ} \mathrm{C}$ in $12 \mathrm{~h}$.

\begin{tabular}{|c|c|c|c|c|c|c|}
\hline Entry & {$\left[\mathrm{Co}^{\mathrm{II}}\right] /[\mathrm{AIBN}] /[\mathrm{VAc}]$} & Complex & Conv.\% & $\mathrm{M}_{\mathrm{n}, \mathrm{GPC}}$ & $\mathrm{M}_{\mathrm{n}, \mathrm{th}}{ }^{\mathrm{a}}$ & $\bigoplus^{\mathrm{b}}$ \\
\hline 1 & $1 / 3.25 / 271$ & $\mathbf{2 a}$ & 42 & 16800 & 9800 & 1.60 \\
\hline 2 & & $\mathbf{2 b}$ & 50 & 10200 & 11700 & 1.73 \\
\hline 3 & & $2 c$ & 72 & 67500 & 16800 & 2.28 \\
\hline 4 & $1 / 3.25 / 542$ & $\mathbf{2 a}$ & 40 & 14300 & 18700 & 2.12 \\
\hline 5 & & $\mathbf{2 b}$ & 33 & 8200 & 15400 & 1.42 \\
\hline 6 & & $2 c$ & 55 & 54600 & 25700 & 2.10 \\
\hline 7 & $1 / 3.25 / 1084$ & $\mathbf{2 a}$ & 12 & 13800 & 11200 & 2.28 \\
\hline 8 & & $2 \mathbf{b}$ & 19 & 3200 & 17700 & 2.10 \\
\hline 9 & & $2 c$ & 25 & 46500 & 23300 & 2.29 \\
\hline
\end{tabular}

a $\mathrm{M}_{\mathrm{n}, \mathrm{th}}=[\mathrm{VAc}]_{\mathrm{O}} /[\mathrm{Co}]_{0} \times \mathrm{M}_{\mathrm{W}(\text { monomer })} \times \operatorname{conv}(\%)$.

b $Đ=\mathrm{M}_{\mathrm{w}, \mathrm{gpc}} / \mathrm{M}_{\mathrm{n}, \mathrm{gpc}}$. 
three $\mathrm{Co}$ (II) complexes were able to mediate the radical polymerization of VAc, but with different rates and levels of control, under these conditions. The conversion curves evidence a shorter induction period as compared with CMRP of VAc in the absence of DMSO in all cases (Fig. 8). Đs were actually broader, with more deviation between theoretical and experimental molecular weights indicating that the VAc polymerizations in the presence of DMSO mediated by $2 \mathbf{a}-\mathbf{c}$ were not preventing termination reactions. The polymerization control has not demonstrated to be improved, as can be verified by the molecular weight deviation and the broader molecular weight distribution (Fig. 9).

In order to further investigate the reason why the polymerization control was not improved, we investigated the complexes $\mathbf{2 a - c}$ in the presence of DMSO. The new Co species formed in solution in the presence of DMSO ([DMSO]/[Co] = 1) were identified by cyclic voltammetry. Experimentally determined electrochemical parameters for complexes $\mathbf{2 a - c}$ with DMSO are collected in Table 4, which shows the half-wave potentials $\left(E_{1 / 2}\right)$ and peak-to-peak separation $(\Delta E)$. The $\Delta E$ for all complexes with DMSO is something lower than without DMSO, indicating an increase in the redox reversibility (Table 4 ). The $\Delta E$ (with or without DMSO) are comparable to the ferrocene-ferrocenium couple, indicating that these $\mathrm{Co}^{\mathrm{II}} / \mathrm{Co}^{\mathrm{III}}$ couples are facile and reversible. Further, a computational

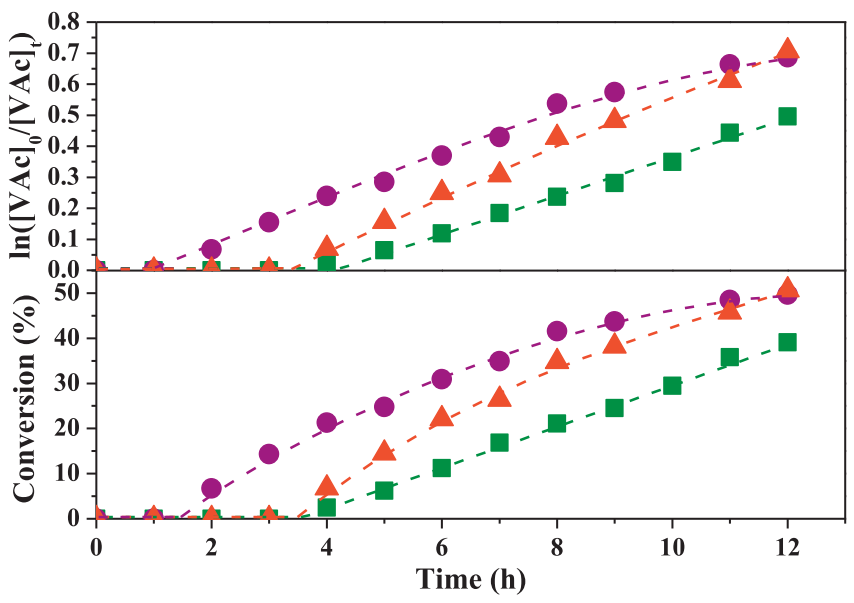

Fig. 8. Dependence of $\ln \left([\mathrm{VAc}]_{0} /[\mathrm{VAc}]_{\mathrm{t}}\right)$ and conversion on the reaction time for CMRP of VAc with 2a ( $\mathbf{\square}), \mathbf{2 b}(\bullet)$ and $\mathbf{2 c}(\mathbf{\Delta})$; [Co]/[AIBN]/[VAc]/[DMSO] = 1/3.25/ $542 / 1$ with $40 \mu \mathrm{mol}$ of complex in bulk at $65^{\circ} \mathrm{C}$.

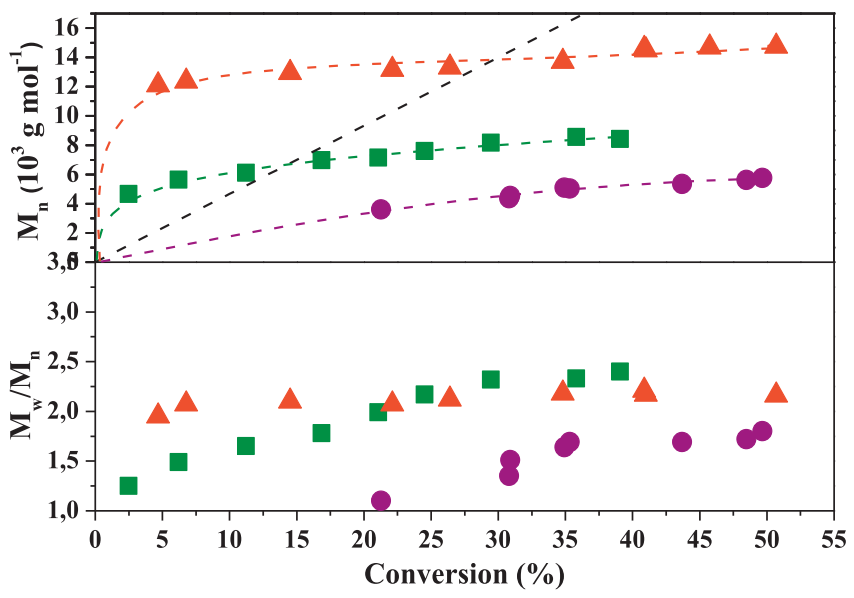

Fig. 9. Dependence of $M_{n}$ and $Đ$ on the conversion for CMRP of VAc with 2a ( $\left.\mathbf{\square}\right), \mathbf{2 b}$ (•) and 2c $(\boldsymbol{\Delta})$; [Co]/[AIBN]/[VAc]/[DMSO] = 1/3.25/542/1 with $40 \mu \mathrm{mol}$ of complex in bulk at $65^{\circ} \mathrm{C}$. $\mathrm{M}_{\mathrm{n} \text { (theor) }}$ (black dashed-line). investigation was carried out to investigate the coordination mode and arrangement of the DMSO and VAc radical ligands in the Co center (2a-c) (Fig. 10). As can be verified, DMSO, bonded through

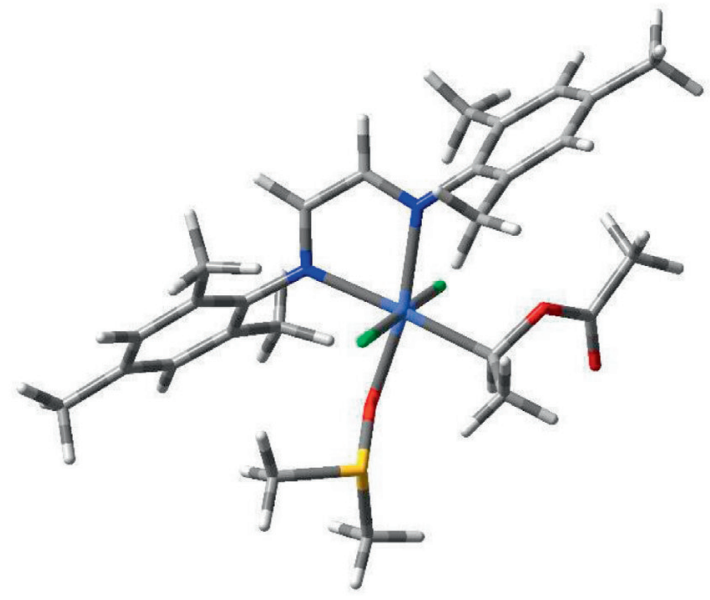

Complex 2a + DMSO + VAc

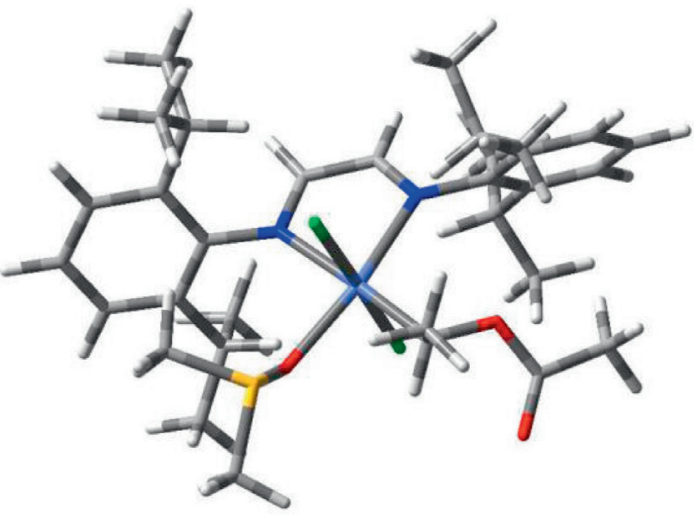

Complex 2b + DMSO + Vac

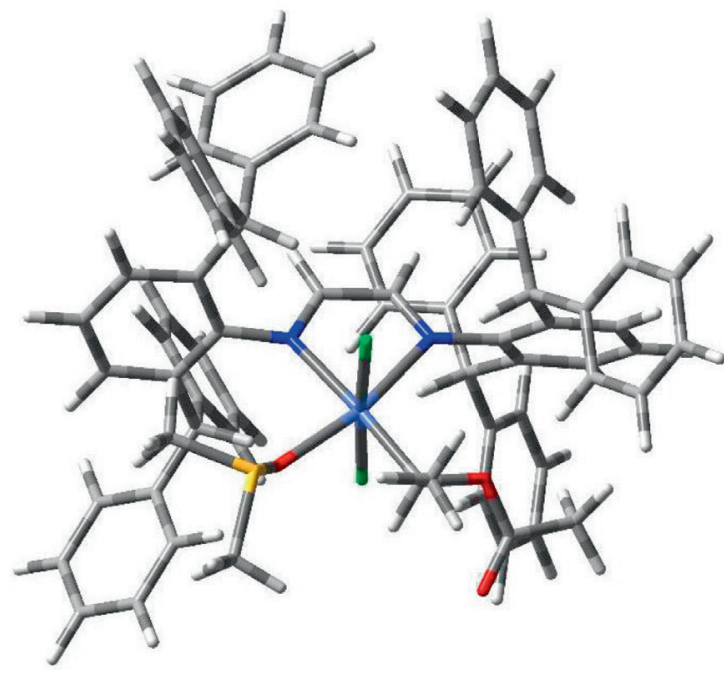

$$
\text { Complex 2c }+ \text { DMSO }+ \text { Vac }
$$

Fig. 10. Representation of DMSO and VAc coordinated to the complexes $\mathbf{2 a}(\mathrm{A}), \mathbf{2 b}$ (B), and 2c (C). 
$\mathrm{O}$, and VAc radical ligands are cis-positioned each other around the Co centre according to a distorted octahedron, strongly influenciated by the five-membered ring.

Such structures have multiplicity $\mathrm{M}=3$ (triplet) as a result of the incorporation of VAc as a free radical. Different from the expected, results of the calculations involving the VAc radical and DMSO-Co- $\alpha$-diimine complexes show a geometric arrangement different from that reported by Debuigne et al. [52] These results help explain why the VAc polymerization in the presence of DMSO was inadequately controlled by complexes $\mathbf{2 a - c}$. In addition to the lack of trans-labilizing effect in the axial plan in these complexes to facilitate the weakening of the $\mathrm{C}-\mathrm{Co}$ bond, the arrangement involving the VAC radical and DMSO-Co- $\alpha$-diimine complexes exerts greater steric hindrance in the Co centre, which hinders the trapping of the propagating radical.

These statements can be further confirmed by the comparison between the thermodynamic parameters obtained to VAc bonded to the Co complexes in the presence and absence of DMSO (Table 6, Scheme 4). According to the calculations, the variation of $\Delta G$ between the [(2a-c)-VAc] and [(2a-c)-VAc-DMSO] species shows

Table 6

Thermodynamic parameters determined to the cobalt complexes [Co-VAc] e [Co-VAcDMSO].

\begin{tabular}{llll}
\hline Complexes & $\Delta \mathrm{G}^{\mathrm{a}}(\mathrm{kJ} / \mathrm{mol})$ & $\Delta \mathrm{H}(\mathrm{kJ} / \mathrm{mol})$ & $\mathrm{T} \Delta \mathrm{S}(\mathrm{kJ} / \mathrm{mol})$ \\
\hline [2a-VAc] & 49.74 & -22.59 & -72.33 \\
[2a-VAc-DMSO] & 95.83 & -24.00 & -119.83 \\
[2b-VAc] & 37.92 & -36.53 & -74.45 \\
[2b-VAc-DMSO] & 88.63 & -38.04 & -126.67 \\
[2c-VAc] & -367.33 & -228.59 & 138.34 \\
[2c-VAc-DMSO] & -74.34 & -228.64 & -154.30 \\
\hline
\end{tabular}

${ }^{\mathrm{a}}$ The thermodynamic parameters were calculated from the following chemical equations:

Co- $\alpha$-diimines + VAc $\rightarrow[$ Co-VAc $]$.

Co- $\alpha$-diimines + VAc + DMSO $\rightarrow[$ Co-VAc-DMSO $]$.

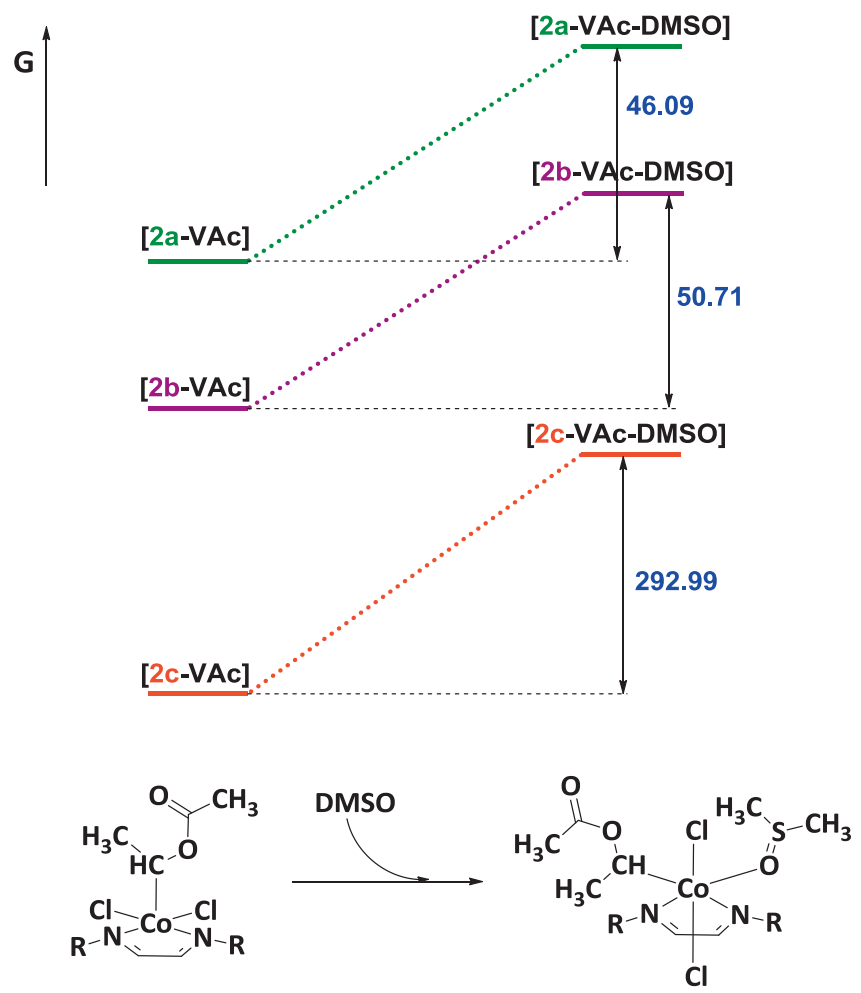

Scheme 4. Gibbs free energy diagram relating the differences between the energies of complexes [Co-VAc] and [Co-VAc-DMSO] that the alkyl-Co complexes obtained in the presence of DMSO are much less favoured than those in the absence of DMSO. The most important factor contributing to achieve the more thermodynamically favoured species is the entropy required to bring together the initial complex and the alkyl-Co complex.

\section{Conclusion}

Three cobalt(II)- $\boldsymbol{\alpha}$-diimine complexes (2a-c) were prepared and studied by FTIR, UV-Vis, cyclic voltammetry, electron paramagnetic resonance spectroscopy, and computational methods. The DT-CMRP of VAc mediated by $\mathbf{2 a - c}$ as a function of time under established optimal conditions ([VAc]/[AIBN]/[Co] = 542/3.25/1 at $65^{\circ} \mathrm{C}$ ) were first order in monomer, as assessed by the linear dependence of $\ln \left([\mathrm{M}]_{0} /[\mathrm{M}]_{\mathrm{t}}\right)$ versus time. The kinetics constant was measured by the slope of the linear graph, $\ln [V A c]_{0} /[\mathrm{VAc}]_{\mathrm{t}}$ versus time $\left(k_{\mathrm{obs}}=1.96 \times 10^{-5} \cdot \mathrm{s}^{-1}\right.$ for $\mathbf{2 a}, k_{\mathrm{obs}}=1.62 \times 10^{-5} \cdot \mathrm{s}^{-1}$ for 2b, and $k_{\mathrm{obs}}=2.55 \times 10^{-5} \cdot \mathrm{s}^{-1}$ for $\mathbf{2 c}$ ). The data show smaller discrepancy between the observed and calculated molecular weights, and narrower molecular weight distribution were obtained for less sterically hindered complexes. Computational investigations and electrochemical studies associated with polymerization kinetics allowed us to comprehend how steric effects may modulate the catalytic reactivity of $\mathbf{2 a - c}$. The RT-CMRP of VAc mediated by $\mathbf{2 a}-\mathbf{c}$ induced by the presence of DMSO, at proportion [Co]/ $\left[\right.$ AIBN] $/\left[\right.$ VAc] $/[$ DMSO $]=1 / 3.25 / 542 / 1$, was conducted at $65^{\circ} \mathrm{C}$. However, no improvement was observed in polymerization control, as verified by the molecular weight deviation and the broader molecular weight distribution. DFT results suggest that the $\mathrm{O}$ bonded DMSO and VAc radical ligands are cis-positioned each other around the Co centre according to a distorted octahedron. Perhaps, this arrangement involving the VAc radical and DMSOCo-diimine complexes exerts greater steric hindrance in the Co centre, which hinders the trapping of the propagating radical.

\section{Experimental section}

\subsection{General remarks}

All reagents were purchased from Aldrich Chemical Co. All reactions and manipulations were performed under nitrogen atmosphere using standard Schlenk techniques. Vinyl acetate (VAc) (>99\%) was washed with $5 \% \mathrm{NaOH}$ solution, dried over anhydrous $\mathrm{Mg}_{2} \mathrm{SO}_{4}$, degassed by several freeze-thawing cycles before being distilled from $\mathrm{CaH}_{2}$ and stored at $-18{ }^{\circ} \mathrm{C}$ under nitrogen. Tetrabutylammonium hexafluorophosphate $\left(n-\mathrm{Bu}_{4} \mathrm{NPF}_{6}\right)$ and $2,2^{\prime}$-Azobis(2-methylpropionitrile) solution (AIBN) (0.2 M in toluene) were used as acquired.

\subsection{Synthesis of ligands (R-DAB)}

The $\alpha$-diimine ligands (Mes- $\mathrm{N}=\mathrm{CH}-\mathrm{CH}=\mathrm{N}-\mathrm{Mes}$ ) (1a) and (Dipp- $\mathrm{N}=\mathrm{CH}-\mathrm{CH}=\mathrm{N}-$ Dipp) (1) $)$ were synthesized using a modification of the preparation described by Arduengo [32], involving treatment of the respective solution of amine $(28 \mathrm{mmol}, 2.15$ equivalents) in $n$-propanol with glyoxal $40 \%$ (13 mmol, 1 equivalent) in $n$-propanol (50\% in water). The ligand (Dipp*$-\mathrm{N}=\mathrm{CH}-\mathrm{CH}=\mathrm{N}-$ Dipp $^{*}$ ) (1c) was prepared as described by Markó [33]. All these $\alpha$-diimines were yielded as yellow powders.

Ligand 1a: Yield: 83\%; (a) UV-Vis: $\lambda_{\max (\mathrm{n})}(\mathrm{nm}), \varepsilon_{\max (\mathrm{n})}\left[\mathrm{M}^{-1}\right.$ $\left.\mathrm{cm}^{-1}\right]: \quad \lambda_{\max (1)}$ (236), $\varepsilon_{\max (1)}$ [99,150]; $\lambda_{\max (2)} \quad(259), \quad \varepsilon_{\max (2)}$ [66,670]; $\lambda_{\max (3)}(365), \varepsilon_{\max (3)}[27,532] ;$ (b) IR $(\mathrm{KBr}): v_{\mathrm{x}}\left(\mathrm{cm}^{-1}\right): v_{\mathrm{C}=\mathrm{N}}$ (1612); (c) ${ }^{1} \mathrm{H}$ NMR $\left(\mathrm{CDCl}_{3}, \delta\right): 8.10(2 \mathrm{H},-\mathrm{C}=\mathrm{N}), 6.91\left(4 \mathrm{H}, \mathrm{H}_{\text {aryl }}\right)$, $2.30\left(6 \mathrm{H},-\mathrm{CH}_{3}\right), 2.16\left(12 \mathrm{H},-\mathrm{CH}_{3}\right)$; (d) ${ }^{13} \mathrm{C} \mathrm{NMR}\left(\mathrm{CDCl}_{3}, \delta\right)$ : 
$163.48(\mathrm{C}=\mathrm{N}), 147.44\left(\mathrm{C}_{\mathrm{Ar}}-\mathrm{N}\right), 134.25,128.98,126.55,20.76(\mathrm{p}-$ $\left.\mathrm{CH}_{3}\right), 18.20\left(\mathrm{o}, \mathrm{O}^{\prime}-\mathrm{CH}_{3}\right)$.

Ligand 1b: Yield: 70\%; (a) UV-Vis: $\lambda_{\max (\mathrm{n})}(\mathrm{nm}), \varepsilon_{\max (\mathrm{n})}\left[\mathrm{M}^{-1}\right.$ $\left.\mathrm{cm}^{-1}\right]: \quad \lambda_{\max (1)}$ (231), $\varepsilon_{\max (1)}$ [90,330]; $\lambda_{\max (2)} \quad(256), \quad \varepsilon_{\max (2)}$ [38,660]; $\lambda_{\max (3)}$ (357), $\varepsilon_{\max (3)}[10,435] ;$ (b) IR (KBr): $v_{\mathrm{x}}\left(\mathrm{cm}^{-1}\right): v_{\mathrm{C}=\mathrm{N}}$ (1624); (c) ${ }^{1} \mathrm{H}$ NMR $\left(\mathrm{CDCl}_{3}, \delta\right): 8.10(2 \mathrm{H},-\mathrm{C}=\mathrm{N}), 7.18\left(4 \mathrm{H}, \mathrm{H}_{\text {aryl }}\right)$, $7.17\left(2 \mathrm{H}, \mathrm{H}_{\text {aryl }}\right), 2.94\left(4 \mathrm{H},-\mathrm{CH}\left(\mathrm{CH}_{3}\right)_{2}\right), 1.20\left(24 \mathrm{H},-\mathrm{CH}\left(\mathrm{CH}_{3}\right)_{2}\right)$; (d) ${ }^{13} \mathrm{C}$ NMR ( $\left.\mathrm{CDCl}_{3}, \delta\right): 163.07(\mathrm{C}=\mathrm{N}), 147.99\left(\mathrm{C}_{\mathrm{Ar}}-\mathrm{N}\right), 136.69$, 125.09, 123.15, $28.03\left(-\mathrm{CH}\left(\mathrm{CH}_{3}\right)_{2}\right), 23.36\left(-\mathrm{CH}\left(\mathrm{CH}_{3}\right)_{2}\right)$.

Ligand 1c: Yield: 85\%; (a) UV-Vis: $\lambda_{\max (\mathrm{n})}(\mathrm{nm}), \varepsilon_{\max (\mathrm{n})}\left[\mathrm{M}^{-1}\right.$ $\mathrm{cm}^{-1}$ ]: $\lambda_{\max (1)}$ (231), $\varepsilon_{\max (1)}$ [89,399]; $\lambda_{\max (2)} \quad(259), \quad \varepsilon_{\max (2)}$ [42,531]; $\lambda_{\max (3)}(297), \varepsilon_{\max (3)}$ [19,924]; (b) IR $(\mathrm{KBr}): v_{\mathrm{x}}\left(\mathrm{cm}^{-1}\right): v_{\mathrm{C}=\mathrm{N}}$ (1624); (c) ${ }^{1} \mathrm{H} \mathrm{NMR}\left(\mathrm{CDCl}_{3}, \delta\right): 7.29-7.21$ and 7.10-7.08 $(42 \mathrm{H}=2 \mathrm{H}$, $-\mathrm{C}=\mathrm{N}$ and $\left.40 \mathrm{H},-\mathrm{CH}(\mathrm{Ph})_{2}\right), 6.38\left(4 \mathrm{H}, \mathrm{H}_{\text {aryl }}\right), 5.45\left(4 \mathrm{H},-\mathrm{CH}(\mathrm{Ph})_{2}\right)$, $2.01\left(6 \mathrm{H}, \mathrm{p}-\mathrm{CH}_{3}\right)$; (d) ${ }^{13} \mathrm{C}$ NMR $\left(\mathrm{CDCl}_{3}, \delta\right): 143.78-142.76(\mathrm{C}=\mathrm{N}$ and $\left.\mathrm{C}_{\mathrm{Ar}}-\mathrm{N}\right), 129.53\left(\mathrm{C}_{\mathrm{Ar}}\right.$ and $\left.-\mathrm{CH}(\mathrm{Ph})_{2}\right), 129.51-128,24(-\mathrm{CH}$ $\left.(\mathrm{Ph})_{2}\right), 126.57\left(-\mathrm{CH}(\mathrm{Ph})_{2}\right), 52.38\left(-\mathrm{CH}(\mathrm{Ph})_{2}\right), 21.00\left(-\mathrm{CH}(\mathrm{Ph})_{2}\right)$.

\subsection{Synthesis of $\left[\mathrm{CoCl}_{2}(R-D A B)\right]$}

Degassed acetone $(50 \mathrm{~mL})$ was added to anhydrous $\mathrm{CoCl}_{2}$ (1 $\mathrm{mmol}$ ) in a Schlenk vessel. After that, this solution was treated by adding the respective ligand $(\mathrm{R}-\mathrm{N}=\mathrm{CH}-\mathrm{CH}=\mathrm{N}-\mathrm{R})(1 \mathrm{mmol})$ in a mixture of acetone and dichloromethane 1:1 $(25 \mathrm{~mL})$. The reaction mixture was stirred at $40{ }^{\circ} \mathrm{C}$ for $5 \mathrm{~h}$. The volume was partially reduced and the precipitate formed was isolated by filtration. The solid was washed with small portions of cold $n$-pentane $(3 \times$ $15 \mathrm{~mL}$ ) to remove excess ligand. This procedure was similar to those described by Barral [16] and Avilés [18].

Complex 2a: Yield: 65\%; (a) UV-Vis: $\lambda_{\max (\mathrm{n})}(\mathrm{nm}), \varepsilon_{\max (\mathrm{n})}\left[\mathrm{M}^{-1}\right.$ $\left.\mathrm{cm}^{-1}\right]: \lambda_{\max (1)}$ (234), $\varepsilon_{\max (1)}[100,785] ; \lambda_{\max (2)}$ (326), $\varepsilon_{\max (2)}$ [66,900]; $\lambda_{\max (3)}$ (502), $\varepsilon_{\max (3)}$ [9336], $\lambda_{\max (4)}$ (592), $\varepsilon_{\max (4)}$ [4231]; (b) IR (CsI): $v_{\mathrm{x}}\left(\mathrm{cm}^{-1}\right): v_{\mathrm{C}=\mathrm{N}}(1593), v_{a s \mathrm{Co}-\mathrm{Cl}}(343), v_{\text {sCo-Cl }}(312)$, $v_{\text {Co-N }}$ (280); (c) Anal. calculated for $\mathrm{C}_{20} \mathrm{H}_{24} \mathrm{CoN}_{2} \mathrm{Cl}_{2}$ : C, 56.89; $\mathrm{H}$, 5.73; N, 6.63, found: C, 56.79; $\mathrm{H}, 5.78 ; \mathrm{N}, 6.60$.

Complex 2b: Yield: 84\%; (a) UV-Vis: $\lambda_{\max (\mathrm{n})}(\mathrm{nm}), \varepsilon_{\max (\mathrm{n})}\left[\mathrm{M}^{-1}\right.$ $\mathrm{cm}^{-1}$ ]: $\lambda_{\max (1)}$ (231), $\varepsilon_{\max (1)}$ [100,578]; $\lambda_{\max (2)}$ (323), $\varepsilon_{\max (2)}$ [43,869]; $\lambda_{\max (3)}$ (406), $\varepsilon_{\max (3)}[18,212], \lambda_{\max (4)}$ (631), $\varepsilon_{\max (4)}$ [3035]; (b) IR (CsI): $v_{\mathrm{x}}\left(\mathrm{cm}^{-1}\right): v_{\mathrm{C}=\mathrm{N}}(1600), v_{a s \mathrm{Co}-\mathrm{Cl}}(310), v_{\mathrm{s} \text { Co-Cl }}$ (300), $v_{\mathrm{Co}-\mathrm{N}}$ (279); (c) Anal. calculated for $\mathrm{C}_{26} \mathrm{H}_{36} \mathrm{CoN}_{2} \mathrm{Cl}_{2}: \mathrm{C}$, 61.66; H, 7.17; N, 5.53, found: C, 61.41; H, 7.26; N, 5.62.

Complex 2c: Yield: 77\%; (a) UV-Vis: $\lambda_{\max (\mathrm{n})}(\mathrm{nm}), \varepsilon_{\max (\mathrm{n})}\left[\mathrm{M}^{-1}\right.$ $\mathrm{cm}^{-1}$ ]: $\lambda_{\max (1)}$ (231), $\varepsilon_{\max (1)}$ [94,483]; $\lambda_{\max (2)} \quad(260), \quad \varepsilon_{\max (2)}$ [33,597]; $\lambda_{\max (3)}$ (521), $\varepsilon_{\max (3)}$ [3762], $\lambda_{\max (4)}$ (626), $\varepsilon_{\max (4)}$ [3295]; (b) IR (CsI): $v_{\mathrm{x}}\left(\mathrm{cm}^{-1}\right): v_{\mathrm{C}=\mathrm{N}}(1630), v_{a s \mathrm{Co}-\mathrm{Cl}}(312), v_{\mathrm{sCo}-\mathrm{Cl}}(297)$, $v_{\text {Co-N }}$ (279); (c) Anal. calculated for $\mathrm{C}_{66} \mathrm{H}_{52} \mathrm{CoN}_{2} \mathrm{Cl}_{2}: \mathrm{C}, 79.04 ; \mathrm{H}$, 5.23; N, 2.79, found: C, 78.89; H, 5.21; N, 2.67.

\subsection{Analyses}

Infrared spectra were obtained with thin sample films on $\mathrm{KBr}$ discs on a Shimadzu IRAffinity-1 FT-IR spectrometer. Cyclic voltammetry measurements were conducted using a Metrohm Autolab PGSTAT204 potentiostat/galvanostat with a stationary platinum disk and a wire as working and auxiliary electrodes, respectively, operated by Nova 1.10 software. The reference electrode was $\mathrm{Ag} / \mathrm{AgCl}$ in $3 \mathrm{~mol} \mathrm{~L}^{-1} \mathrm{KCl}$. The measurements were performed at $25{ }^{\circ} \mathrm{C} \pm 0.1$, under nitrogen atmosphere, in $\mathrm{CH}_{2} \mathrm{Cl}_{2}$ with $0.1 \mathrm{~mol} \mathrm{~L}^{-1}$ of $n-\mathrm{Bu}_{4} \mathrm{NPF}_{6}$ and the complex concentration was 1 $\times 10^{-3} \mathrm{~mol} \mathrm{~L}^{-1}$. The $E_{1 / 2}$ values were the arithmetic average of the anodic and cathodic potential peaks $\left(E_{\mathrm{p}, \mathrm{a}}+E_{\mathrm{p}, \mathrm{c}}\right) / 2$. UV/vis spectra were recorded by a PerkinElmer Lambda 25 UV/Vis spectrophotometer in a range from 700 to $200 \mathrm{~nm}$, using $1 \mathrm{~cm}$ path length quartz cells. $\mathrm{CH}_{2} \mathrm{Cl}_{2}$ solutions of the complexes of $1 \times 10^{-2} \mathrm{mM}$ concentrations were used for these measurements. The NMR $\left({ }^{1} \mathrm{H}\right.$; $\left.{ }^{13} \mathrm{C}\left\{{ }^{1} \mathrm{H}\right\}\right)$ spectra were obtained in $\mathrm{CDCl}_{3}$ at $25.0 \pm 0.1{ }^{\circ} \mathrm{C}$ using a
Bruker DRX-400 of $9.4 \mathrm{~T}$. The obtained chemical shifts were reported in ppm relative to TMS. The molecular weights and the molecular weight distribution of the polymers were determined by gel permeation chromatography using a Shimadzu Prominence LC system equipped with a LC-20AD pump, a DGU-20A5 degasser, a CBM-20A communication module, a CTO-20A oven at $40^{\circ} \mathrm{C}$, and a RID-10A detector equipped with two PL gel columns $(5 \mathrm{~m}$ MIXED-C: $30 \mathrm{~cm}, \varnothing=7.5 \mathrm{~mm}$ ). Retention time was calibrated with standard monodispersed polystyrene using HPLC-grade THF as eluent at $40{ }^{\circ} \mathrm{C}$ with a flow rate of $1.0 \mathrm{~mL} \mathrm{~min}^{-1}$. $Đ$ is $\mathrm{M}_{\mathrm{w}} / \mathrm{M}_{\mathrm{n}}$. Theoretical molecular weights were calculated without considering the end groups according to the following equation: $M_{n, t h}=$ $\left([\text { Monomer }]_{0} /[\mathrm{Co}]_{0}\right) \times$ Conversion $\times \mathrm{M}_{\text {Wmonomer }}$.

\subsection{EPR mesurements}

The $\mathrm{Co}^{\mathrm{II}}$ complexes in powder and frozen $\mathrm{CH}_{2} \mathrm{Cl}_{2}$ solution forms were placed into quartz tubes and introduced in a rectangular microwave cavity in the Varian X-band equipment (Model E-109) using an Oxford continuous helium flow cryostat to obtain EPR spectra. The measurements were taken at a temperature of $5.0 \mathrm{~K}$. EPR conditions were as follows: $100 \mathrm{kHz}$ field modulation with amplitude of $1.0 \mathrm{mT}, 5 \mathrm{~mW}$ of microwave power, gain of 1000 , centre field $260 \mathrm{mT}$ and scan range of $500 \mathrm{mT}$, time constant of 0.128 $\mathrm{s}$, and scan field at 4 min collecting 4096 points.

\subsection{Computational details}

As the $\mathrm{Co}(\mathrm{II})$ complexes under study are high-spin pseudotetrahedral compounds $(S=3 / 2)[39,58]$, all calculations were performed considering multiplicity equal 4 , except in the situations described in the discussion of the results. The structure of the compounds under study were optimized using the density functional theory (DFT) at the level of the hybrid functional PBE0 [53], implemented in Gaussian 09 [43], using the basis set TZVP [54]. The optimizations and calculation of the vibrational frequencies were conducted without any symmetry constraints. The thermodynamic parameters $\Delta \mathrm{H}, \Delta \mathrm{G}$, and $\mathrm{T} \Delta \mathrm{S}$ were estimated for the formation of some of the studied complexes, being calculated from thermochemical data generated from the calculation of the vibrational frequencies. The software package Orca 4.0.0.2 [55] was employed to calculate, for the isolated $\mathrm{Co}(\mathrm{II})$ complexes, the EPR g-tensors and their corresponding zero-field splitting (ZFS) tensors [56], expressed in terms of the axial anisotropy parameter (D), and the rhombicity (E/D), using the DFT generalized gradient approximation exchange-correlation functional revPBE [57]. These calculations were performed using the aforementioned basis set combined with the auxiliary basis set def2/J [58]. The g-tensors, $\mathrm{D}$, and $\mathrm{E} / \mathrm{D}$ were estimated taking the centre of the electronic charge as reference. In order to reproduce the experimental conditions, some simulations involving these compounds were also done considering dichloromethane as solvent, using the model IEFPCM $[59,60]$ to build a dielectric continuum with the characteristics of such solvent, in a self-consistent reaction field procedure [43]. To this end, all structures were reoptimized. Additionally, the structures of these solvated complexes coordinated to DMSO, and also coordinated to DMSO and a vinyl monomer, were optimized.

\subsection{Procedure for CMRP}

The initiator solution (AIBN) was placed in a Schlenk tube containing a magnet bar and capped with a rubber septum. By three vacuum-nitrogen cycles all toluene was dried and air was expelled before the cobalt complex and the monomer were added. All liquids were handled with dried syringes under nitrogen. The tube 
was capped under $\mathrm{N}_{2}$ atmosphere using Schlenk techniques and the reaction mixture was then magnetically stirred and heated in a thermostated bath at $65{ }^{\circ} \mathrm{C}$. At appropriate time intervals, the samples were withdrawn and analyzed by SEC-THF to obtain the molecular parameters (using PS calibration) and by GC to determine monomer conversion, after addition of TEMPO to neutralize the radicals.

\section{Acknowledgements}

The authors are indebted to the financial support from FAPESP (Proc. 2013/11883-1), CNPq (Proc. 307443/2015-9), FAPEMIG (Proc. CEX - APQ-00583-13) and Prope (Proc. 2180/002/14PROPe/CDC). The $400 \mathrm{MHz}-\mathrm{NMR}$ analyses were performed at the Instituto de Química de São Carlos/USP, São Carlos, SP, Brazil.

\section{Appendix A. Supplementary material}

Supplementary data associated with this article can be found, in the online version, at https://doi.org/10.1016/j.ica.2017.11.041.

\section{References}

[1] A. Debuigne, J.R. Caille, R. Jérôme, Angew. Chem. 117 (2005) 1125-1128.

[2] C.S. Hsu, T.Y. Yang, C.H. Peng, Polym. Chem. 5 (2014) 3867-3875.

[3] C. Detrembleur, D.-L. Versace, Y. Piette, M. Hurtgen, C. Jérôme, J. Lalevée, A Debuigne, Polym. Chem. 3 (2012) 1856-1866.

[4] A.N. Morin, C. Detrembleur, C. Jérôme, P.D. Tullio, R. Poli, A. Debuigne, Macromolecules 46 (2013) 4303-4312.

[5] J.W. Rhim, H.B. Park, C.S. Lee, J.H. Jun, D.S. Kim, Y.M. Lee, J. Membr. Sci. 238 (2004) 143-151.

[6] M.S.P. Shaffer, A.H. Windle, Adv. Mater. 11 (1999) 937-941.

[7] E. Chiellini, A. Corti, S. D’Antone, R. Solaro, Prog. Polym. Sci. 28 (2003) $963-$ 1014.

[8] Y.M. Ha, T. Amna, M.H. Kim, H.C. Kim, M.S. Hassan, M.S. Khil, Colloids Surf. B 102 (2013) 795-802.

[9] C. Detrembleur, A. Debuigne, R. Bryaskova, B. Charleux, R. Jérôme, Macromol Rapid Commun. 27 (2006) 37-41.

[10] M. Hurtgen, A. Debuigne, C. Jérôme, C. Detrembleur, Macromolecules 43 (2009) 886-894.

[11] A. Debuigne, R. Poli, C. Jérôme, R. Jérôme, C. Detrembleur, Prog. Polym. Sci. 34 (2009) 211-239.

[12] B.B. Wayland, G. Poszmik, S.L. Mukerjee, M. Fryd, J. Am. Chem. Soc. 116 (1994) 7943-7944.

[13] L.D. Arvanitopoulos, M.P. Gruel, H.J. Harwood, Polym. Prepr. 35 (1994) 549550.

[14] C.-M. Liao, C.-C. Hsu, F.-S. Wang, B.B. Wayland, C.-H. Peng, Polym. Chem. 4 (2013) 3098-3104.

[15] G.V. Koten, K. Vrieze, Adv. Organomet. Chem. 21 (1982) 151-239. and references cited therein.

[16] M.C. Barral, E. Delgado, E.G. Puebla, R.J. Aparicio, A. Monge, C. Del Pino, A. Santos, Inorg. Chim. Acta 74 (1983) 101-107.

[17] M.J. Camazón, A.A. Valdés, J.R. Masaguer, M.C.N. Ranninger, A.A. Valdés, J.R. Masaguer M.C.N. Ranninger, Transition Met. Chem. 11 (1986) 334-336.

[18] V. Rosa, P.J. Gonzalez, T. Avilés, P.T. Gomes, R. Welter, A.C. Rizzi, M.C.G. Passeggi, C.D. Brondino, Eur. J. Inorg. Chem. 23 (2006) 4761-4769.

[19] V. Rosa, S.A. Carabineiro, T. Avilés, P.T. Gomes, R. Welter, J.M. Campos, M.R. Ribeiro, J. Organomet. Chem. 693 (2008) 769-775.

[20] X. Jia, H. Liu, Y. Hu, Q. Dai, J. Bi, C. Bai, X. Zhang, Chin. J. Catal. 34 (2013) 1560 1569.

[21] H.T. Dieck, M. Haarich, J. Organomet. Chem. 291 (1985) 71-87.

[22] T. Pugh, S.D. Cosham, J.A. Hamilton, A.J. Kingsley, A.L. Johnson, Inorg. Chem. 52 (2013) 13719-13729.

[23] (a) V.C. Gibson, R.K. O'Reilly, D.F. Wass, A.J.P. White, D.J. Williams, Macromolecules 36 (2003) 2591-2593.

[24] (a) R.K. O’Reilly, M.P. Shaver, V.C. Gibson, Inorg. Chim. Acta 359 (2006) $4417-$ 4420 (b) R.K. O'Reilly, M.P. Shaver, V.C. Gibson, A.J.P. White, Macromolecules 40 (2007) 7441-7452.

[25] Z. Xue, R. Poli, J. Polym. Sci.: Polym. Chem. 51 (2013) 3494-3504.

[26] J.M. Kliegman, R.K. Barnes, Pergamon Press 26 (1970) 2555-2560.

[27] H.T. Dieck, K.D. Franz, W. Majunke, Z. Naturforsch 30b (1975) 922-925.

[28] L.H. Staal, D.J. Stufkens, A. Oskam, Inorg. Chim. Acta 26 (1978) 255-262.

[29] J. Reinhold, R. Benedix, P. Birner, H. Hennig, Inorg. Chim. Acta 33 (1979) 209213.

[30] R.S. Herrick, C.J. Ziegler, H. Bohan, M. Corey, M. Eskander, J. Giguere, N. McMichen, I.E. Wrona, J. Organomet. Chem. 687 (2003) 178-184.

[31] (a) L. Delaude, M. Szypa, A. Demonceau, A.F. Noels, Adv. Synth. Catal. 344 (2002) 749-756;

(b) F. Nourmohammadian, M.D. Gholami, Lett. Org. Chem. 9 (2012) 720-731.

[32] A.J. Arduengo III, R. Krafczyk, R. Schmutzler, Tetrahedron 55 (1999) 1452314534.

[33] G.B. Gelloz, M.A. Siegler, A.L. Spek, B. Tinant, J.N.H. Reek, I.E. Markó, Dalton Trans. 39 (2010) 1444-1446.

[34] J.L. Rhinehart, L.A. Brown, B.K. Long, J. Am. Chem. Soc. 135 (2013) 1631616319.

[35] A. Böttcher, T. Takeuchi, K.I. Hardcastle, T.J. Meade, H.B. Gray, D. Cwikel, M. Kapon, Z. Dori, Inorg. Chem. 36 (1997) 2498-2504.

[36] (a) M. Sieger, M. Wanner, W. Kaim, D.J. Stufkens, T.L. Snoeck, S. Záliš, Inorg. Chem. 42 (2003) 3340-3346;

(b) B. Crociani, M. Nicolini, R.L. Richards, J. Chem. Soc., Dalton Trans. (1978) 1478-1484.

[37] S. Stoll, A. Schweiger, EasySpin, a comprehensive software package for spectral simulation and analysis in EPR, J. Magn. Reson. 178 (2006) 42-55.

[38] Matlab, Mathwork Inc., Natick, MA 01760, 2015.

[39] M. Idešicová, J. Titiš, J. Krzystek, R. Boča, Inorg. Chem. 52 (2013) 9409-9417.

[40] P. Pietrzyk, M. Srebro, M. Radoń, Z. Sojka, A. Michalak, J. Phys. Chem. A 115 (2011) 2316-2324

[41] G. Mathies, R.M. Almeida, P. Gast, J.J.G. Moura, E.J.J. Groenen, J. Phys. Chem. B 116 (2012) 7122-7128.

[42] M. Atanasov, D. Aravena, E. Suturina, E. Bill, D. Maganas, F. Neese, Coord. Chem. Rev. 289-290 (2015) 177-214.

[43] G09: Gaussian 09, Revision E.01. M.J. Frisch, G.W. Trucks, H.B. Schlegel, G.E. Scuseria, M.A. Robb, J.R. Cheeseman, G. Scalmani, V. Barone, B. Mennucci, G.A Petersson, H. Nakatsuji, M. Caricato, X. Li, H.P. Hratchian, A.F. Izmaylov, J. Bloino, G. Zheng, J.L. Sonnenberg, M. Hada, M. Ehara, K. Toyota, R. Fukuda, J. Hasegawa, M. Ishida, T. Nakajima, Y. Honda, O. Kitao, H. Nakai, T. Vreven, J.A. Montgomery, Jr., J.E. Peralta, F. Ogliaro, M. Bearpark, J.J. Heyd, E. Brothers, K.N. Kudin, V.N. Staroverov, T. Keith, R. Kobayashi, J. Normand, K. Raghavachari, A. Rendell, J.C. Burant, S.S. Iyengar, J. Tomasi, M. Cossi, N. Rega, J.M. Millam, M. Klene, J.E. Knox, J.B. Cross, V. Bakken, C. Adamo, J. Jaramillo, R. Gomperts, R.E. Stratmann, O. Yazyev, A.J. Austin, R. Cammi, C. Pomelli, J.W. Ochterski, R.L. Martin, K. Morokuma, V.G. Zakrzewski, G.A. Voth, P. Salvador, J.J. Dannenberg, S. Dapprich, A.D. Daniels, O. Farkas, J.B. Foresman, J.V. Ortiz, J. Cioslowski, D.J. Fox, Gaussian Inc, Wallingford CT, 2015.

[44] H. Fischer, Chem. Rev. 101 (2001) 3581-3610.

[45] C.H. Peng, S. Li, B.B. Wayland, Inorg. Chem. 48 (2009) 5039-5046.

[46] S. Li, B. Bruin, C.H. Peng, M. Fryd, B.B. Wayland, J. Am. Chem. Soc. 130 (2008) 13373-13381.

[47] L. Chiang, L.E.N. Allan, J. Alcantara, M.C.P. Wang, T. Storr, M.P. Shaver, Dalton Trans. 43 (2014) 4295-4304.

[48] A. Debuigne, C. Michaux, C. Jerome, R. Jerome, R. Poli, C. Detrembleur, Chem. Eur. J. 14 (2008) 7623-7637.

[49] A. Debuigne, J. Warnant, R. Jérôme, I. Voets, A. de Keizer, M.A.C. Stuart, C. Detrembleur, Macromolecules 41 (2008) 2353-2360.

[50] A. Debuigne, J.R. Caille, C. Detrembleur, R. Jérôme, Angew. Chem. 44 (2005) 3439-3442.

[51] M.R. Buchmeiser, M.G. Marino, Macromol. Mater. Eng. 297 (2012) 894-901.

[52] A. Debuigne, R. Poli, R. Jérôme, C. Jérôme, C. Detrembleur, ACS Symp. Ser. 1024 (2009) 131-147.

[53] A. Carlo, V. Barone, J. Chem. Phys. 110 (1999) 6158-6170.

[54] A. Schaefer, C. Huber, R. Ahlrichs, J. Chem. Phys, 100 (1994) 5829-5835.

[55] F. Neese, Wiley Interdisciplinary Rev.: Comput. Mol. Sci. 2 (2012) 73-78.

[56] F. Neese, J. Chem. Phys. 127 (2007) 164112.

[57] Y. Zhang, W. Yang, Phys. Rev. Lett. 80 (1998) 890.

[58] F. Weigend, PCCP 8 (2006) 1057-1065.

[59] M. Murrie, Chem. Soc. Rev. 39 (2010) 1986-1995.

[60] J. Tomasi, B. Mennucci, E. Cancès, J. Mol. Struct. (Theochem) 464 (1999) 211 226. 